\title{
Mixing of rhyolite, trachyte and basalt magma erupted from a vertically and laterally zoned reservoir, composite flow P1, Gran Canaria
}

\author{
Armin Freundt and Hans-Ulrich Schmincke \\ GEOMAR, Abteilung Petrologie, Wischhofstrasse 1-3, W-2300 Kiel 14, FRG
}

Received June 11, 1991 / Accepted May 18, 1992

\begin{abstract}
The 14.1 Ma composite welded ignimbrite P1 $\left(45 \mathrm{~km}^{3} \mathrm{DRE}\right)$ on Gran Canaria is compositionally zoned from a felsic lower part to a basaltic top. It is composed of four component magmas mixed in vertically varying proportions: (1) Na-rhyolite $\left(10 \mathrm{~km}^{3}\right)$ zoned from crystal-poor to highly phyric; (2) a continuously zoned, evolved trachyte to sodic trachyandesite magma group $\left(6 \mathrm{~km}^{3}\right)$; (3) a minor fraction of Na-poor trachyandesite $\left(<1 \mathrm{~km}^{3}\right)$; and (4) nearly aphyric basalt $\left(26 \mathrm{~km}^{3}\right)$ zoned from 4.3 to $5.2 \mathrm{wt} \% \mathrm{MgO}$. We distinguish three sites and phases of mixing: (a) Mutual mineral inclusions show that mixing between trachytic and rhyolitic magmas occurred during early stages of their intratelluric crystallization, providing evidence for longterm residence in a common reservoir prior to eruption. This first phase of mixing was retarded by increasing viscosity of the rhyolite magma upon massive anorthoclase precipitation and accumulation. (b) All component magmas probably erupted through a ring-fissure from a common upper-crustal reservoir into which the basalt intruded during eruption. The second phase of mixing occurred during simultaneous withdrawal of magmas from the chamber and ascent through the conduit. The overall withdrawal and mixing pattern evolved in response to pre-eruptive chamber zonation and density and viscosity relationships among the magmas. Minor sectorial variations around the caldera reflect both varying configurations at the conduit entrance and unsteady discharge. (c) During each eruptive pulse, fragmentation and particulate transport in the vent and as pyroclastic flows caused additional mixing by reducing the length scale of heterogeneities. Based on considerations of magma density changes during crystallization, magma temperature constraints, and the pattern of withdrawal during eruption, we propose that eruption tapped the P1 magma chamber during a transient state of concentric zonation, which had resulted from destruction of a formerly layered zonation in order to maintain gravitational equilibrium. Our model of magma chamber zonation at the time of eruption envisages a basal high-density Na-poor trachyandesite layer that was overlain by a cen-
\end{abstract}

tral mass of highly phyric rhyolite magma mantled by a sheath of vertically zoned trachyte-trachyandesite magma along the chamber walls. A conventional model of vertically stacked horizontal layers cannot account for the deduced density relationships nor for the withdrawal pattern.

\section{Introduction}

Magma mixing, advocated by Bunsen (1851) but later dismissed in favor of more elegant physicochemical methods and models (e.g., Bowen 1928), has become widely recognized as an important petrological process during the past three decades (e.g., Anderson 1976; Wright 1971; Wright and Fiske 1971). Also, the recognition of compositionally zoned magma columns (e.g., Smith 1979; Hildreth 1981), based on the discovery of many compositionally zoned ignimbrites (e.g., Lipman et al. 1966; Smith and Bailey 1966; Schmincke 1969 b), was followed by fluid dynamic discussions arguing that convective processes can both create and destroy (i.e., mix) magma zonation (e.g., McBirney 1980; Turner 1980; Blake 1981).

Mixed magma associations have been reported in plutonic rocks (e.g., Vogel and Wilbrand 1978; Wiebe 1987), in extrusive domes and lava flows (e.g., Bacon and Metz 1984; Thompson and Dungan 1985), and in pyroclastic fall and flow deposits (e.g., Macdonald and Katsura 1965; Jørgensen 1980; Sigurdsson and Sparks 1981; Hildreth 1983; Schuraytz et al. 1989). In most studies on magma mixing, two major end-member compositions were identified. A spectacular ignimbrite cooling unit (P1) on Gran Canaria is a mixture of at least 4 endmember compositions erupted from a common reservoir, 3 of which are compositionally zoned.

A general problem is the identification of sites and times of magma mixing. Here, we use mixing structures, chemical variations, and physical modeling in order to determine the mixing mechanisms involved during intra- 


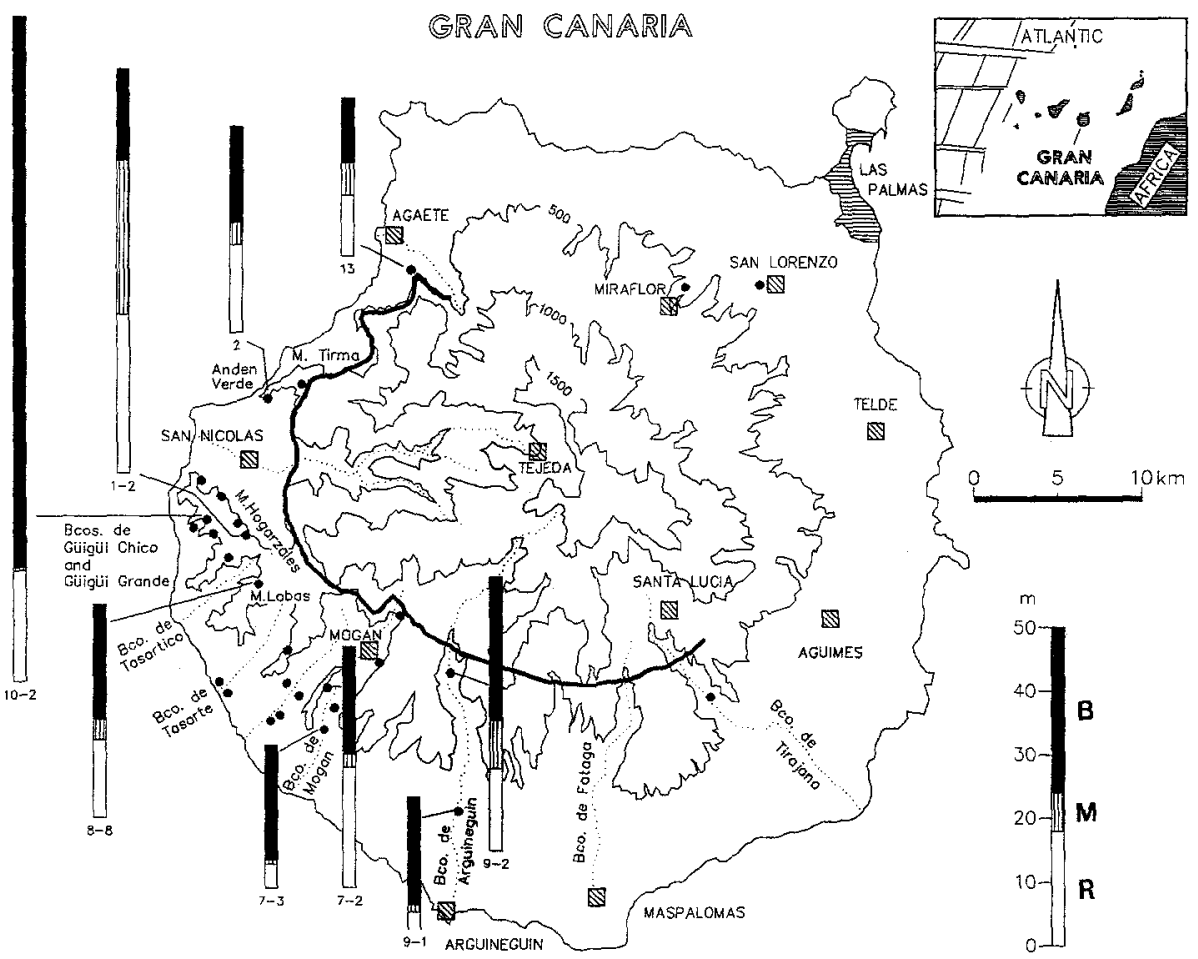

Fig. 1. Map of Gran Canaria showing all major sections of P1 (dots) and selected columnar profiles (with locality numbers). $B$ : basalt, $M$ : mixed rock, $R$ : rhyolite units of $\mathrm{P} 1$. Thick line is the $\mathrm{Te}$ jeda caldera wall, covered by younger rocks in the NE part of the island. $M$.: Montaña (mountain), Bco.: Barranco (canyon) telluric crystallization, evacuation of the magma chamber, and pyroclastic surface transport.

\section{Volcanological setting of P1}

The roughly circular island ( $45 \mathrm{~km}$ diameter) of Gran Canaria in the Canary Islands archipelago (east central Atlantic; $28^{\circ} 00^{\prime} \mathrm{N}$, $15^{\circ} 35^{\prime} \mathrm{W}$ ) can be structurally divided into a Miocene extracaldera facies in the SW and S (Schmincke 1967; 1969a, b) and the resurgent $10-15 \mathrm{~km}$ diameter Tejeda caldera in the center (Schmincke 1967, 1968; Schmincke and Swanson 1966). Younger volcanic rocks cover the NE half of the island. The geology of Gran Canaria has been summarized by Schmincke $(1982 ; 1990)$.

The Miocene extracaldera sequence comprises an underlying complex basaltic shield volcano (Miocene basalt group) capped by a series of felsic ignimbrite and lava cooling units (rhyolitictrachytic Mogán and trachyphonolitic Fataga groups). The composite ignimbrite cooling unit P1 at the base of the Mogán group marks the beginning of voluminous eruption of highly evolved magmas following construction of the basaltic shield. P1 had a total eruptive volume of about $45 \mathrm{~km}^{3}$ radially distributed around the Tejeda caldera. It was emplaced over uneven terrain and ranges in total thickness from 30 to $50 \mathrm{~m}$ in channel sections (reaching over $100 \mathrm{~m}$ in the west; Fig. 1) to commonly 20 to $30 \mathrm{~m}$ in overbank or plateau sections, thinning towards the coast. Detailed sections of cooling unit P1 were logged throughout the island but mostly in the almost continuously exposed SW sector (Fig. 1). Isolated outcrops of P1 show through the cover of younger rocks in the NE half of the island but within the caldera P1 is hidden at depth. Lateral and local variations were studied by detailed mapping of selected areas at the scale of 1:5000, especially in the HogarzalesGüigüi area in the west. An excellent exposure of P1 is the easily accessable roadcut along the San Nicolás - Agaete road at Anden Verde (Fig. 1).

For clarity and brevity, a definition of terms used in the following discussions is given in Table 1.

\section{Stratigraphy of P1}

Schmincke (1969a, b) divided this cooling unit into the lower rhyolitic "porphyry P1", central mixed-rock, and overlying "trachybasalt T1". Here we refer to the entire cooling unit as P1. The partitioning of P1 into three units is easily recognized in the field due to pronounced color changes (Fig. 2). On the basis of textural and compositional characteristics we further distinguish four subunits (R1 to R4) in the rhyolitic part (R), two subunits (M1, M2) in the mixed rock (M) and three subunits (B1 to B3) in the basalt (B), most of which comprise several flow units.

The pink rhyolitic basal vitric unit $R 1(<30 \mathrm{~cm}$ thick) shows an increase in feldspar content from $5 \%$ at the base to $20 \%$ at the top (percentages refer to field-estimates of volume fractions). The top boundary with overlying unit $\mathrm{R} 2$ is marked by a sudden increase in feldspar content and commonly lies below or within the thick basal vitrophyre of P1. Plastically deformed cognate inclusions, which abound in the higher units, are rare in R1. Exceptions are abundant large $(<30 \mathrm{~cm})$ glassy trachyte inclusions in R1 in the Güigüi area and about $30 \%$ microscopic trachyte inclusions in the vitrophyre at $M$. Hogarzales in the west of the island (Fig. 1). Small flattened basaltic inclusions $(<1 \mathrm{~cm})$ in $\mathrm{R} 1$ occur mainly at $M$. Tirma and rarely in other sections.

Unit $R 2$ is 5 to $9 \mathrm{~m}$ thick in channel profiles and comprises a black basal vitrophyre 0.3 to $1 \mathrm{~m}$ thick and a main thickly columnar zone, which is pale reddish brown in its dense microcrystalline lower part to light gray at its finely vesicular top. The majority of flattened inclusions in R2 are light gray, locally yellow or pink rhyolitic fiamme, variable in abundance and size; fiamme up to $1 \mathrm{~m}$ in length and $10 \mathrm{~cm}$ in thickness occur locally. Medium to dark gray, partly dark red trachytic inclusions with feldspar content significantly lower than in the rhyolite (Fig. 3b), are generally smaller but have similar flattening ratios. Dark gray to black trachyandesitic inclusions generally $<15 \mathrm{~cm}$ long are less common than trachytic inclusions and are characterized by small euhedral plagioclase phenocrysts (Fig. 3a, b). The number and size of trachytic to trachyandesitic inclusions increase upwards in unit R2. Inclusions of interbanded rhyolite and trachyte (Fig. $3 \mathrm{~b}$ ) are common, whereas trachyte-trachyandesite banded inclusions are rare. Rare pale red inclusions macroscopically very similar to the tra- 
Table 1. Definition of terms

\section{Inclusions :}

cognate magmatic blebs compositionally distinct from the host rock that were liquid during emplacement (as shown by features such as plastic deformation, chilled margins, oxidation haloes, matrix crystal alignment subparallel with host tuff)

\section{Fiamme:}

plastically deformed clasts compositionally similar to the bulk rock, commonly collapsed pumice; in mixed rocks with subequal component fractions, the distinction between fiamme and inclusions becomes meaningless

Xenoliths, lithics:

accidentally included rock fragments (showing features such as contrasting composition, protruding phenocrysts broken off at clast surfaces, or matrix crystal alignment discordant to host tuff matrix)

Rhyolite phenocrysts/matrix:

having compositions characteristic of the rhyolitic end-member magma

Trachyte phenocrysts/matrix:

having compositions characteristic of the trachyte-trachyandesite end-member magma group

Basalt phenocrysts/matrix:

having compositions characteristic of the basaltic end-member magma

Mixing:

chaotic physical mingling of magmatic components by coherent or particulate flow

Emulsion texture:

mixed texture with sharply defined roundish bodies of one component suspended in the other coherent component

Banded texture:

mixed texture with sharply defined components drawn out into thin parallel, partly crenulate bands

Pore:

any small cavity in a rock, including vesicles and interparticle spaces of any shape

chyandesitic inclusions are less sodic and more andesitic in composition.

Unit $R 3$ is 1.5 to $6 \mathrm{~m}$ thick in channel sections and is generally darker than R2 and R4. The typical colorful speckled appearance is due to the high concentration (ca. $20 \%$, locally up to $50 \%$ ) of a wide range of inclusions. The compositional types of inclusions are the same as in unit R2, but in R3 slightly vesicular to pumiceous trachytic inclusions dominate or are at least equally abundant as the dense rhyolitic inclusions. Vesicular aphyric basaltic inclusions (Fig. $3 \mathrm{c}$ ) increase upwards in abundance.

The sharply bounded unit $R 4$, generally 1 to $4 \mathrm{~m}$ thick $(10 \mathrm{~m}$ maximum at $\mathrm{M}$. Hogarzales), has a light-colored very porous silicic matrix spotted with abundant dark, pumiceous, aphyric basalt inclusions (mostly $<5 \mathrm{~cm}$ ). The content of other inclusions, particularly trachytic ones, is significantly reduced. The content of feldspar crystals in R4 (up to $60 \%$ ) is the maximum for the entire P1 cooling unit.

The rhyolite/mixed rock boundary is always sharp and characterized by an abrupt change to dark red color and significantly lower feldspar content (ca. 15\%). Unit M1, like R4, contains abun- dant pumiceous basalt inclusions. Trachytic inclusions are rare. The common vesicular rhyolite inclusions have flattened but rather irregular shapes and are commonly surrounded by dark selvages, $<1 \mathrm{~cm}$ thick, of dense mixed rock matrix. Rhyolite inclusions are most abundant in the western sector where the mixed rock reaches extreme thicknesses of up to $20 \mathrm{~m}$; elsewhere it is commonly only 0.5 to $3 \mathrm{~m}$ thick.

The boundary with unit $M 2$ is commonly diffuse, but the feldspar content of M2 is only 5 to $10 \%$ and porosity is lower than in M1. The types of inclusions are the same but their content and size is significantly lower. A gradual upward decrease in abundance of feldspars and inclusions occurs locally in place of discrete M1 and M2 units.

The dark-gray to black basalt unit $B 1$ has a dense base in sharp but wavy contact with the underlying mixed rock. B1 is up to $7.5 \mathrm{~m}$ thick but not present in every section. It is compositionally characterized by ca. $5 \%$ large anorthoclase crystals dispersed in the basalt matrix, which itself is nearly aphyric. Rhyolitic inclusions have irregular amoeboid shapes and are strongly vesicular.

The platy to columnar, massive unit $B 2$ makes up the dominant volume of the $\mathrm{P} 1$ basalt and is distinguished from $\mathrm{B} 1$ by a still further reduced content $(<1 \%$ ) of anorthoclase xenocrysts (Fig. 2). Rhyolite inclusions are rare but extremely inflated and generally increase upwards in volume.

Unit B3 is distinguished from B2 primarily by the gradual change from dense to clastic texture (Freundt and Schmincke in preparation 1993; Freundt 1989). Compositional differences between B3 and B2 result only from the continuation of the vertical variations in $\mathrm{B} 2$, with notable increases in feldspar content (back to $5 \%$ ) and in vesicular rhyolitic inclusions having dense basalt rims (Fig. 3d). Trachyte inclusions are absent from B2 and B3 except for a section in the northeast of the island, near Miraflor (Fig. 1), where dm-sized trachyte-trachyandesite inclusions constitute ca. $20 \%$ of the B3 tuff.

\section{Characterization of end-member magmas}

Tuff and inclusion samples cover the spectrum of chemical composition from basalt to rhyolite (Fig. 4). Tuff samples generally contain a mixed mineral assemblage (e.g., oligoclase and anorthoclase in R1 to R4, resorbed anorthoclase and calcic plagioclase in B1 to B3), and the same holds for many inclusions. There are, however, also inclusion/fiamme and tuff samples having equilibrium mineral assemblages and limited compositional range, so we used these to identify 4 magmatic end-members (Fig. 4). The phenocryst phases of all 4 component magmas are distinguishable compositionally, and for the most part optically as well. Detailed descriptions, chemical data and a discussion of the evolution of these end-member magmas are given in Freundt and Schmincke (submitted to J. Petrology). Here, we concentrate on the mixed rocks and give only a brief summary of the end-member magma types. Endmember magma volumes are derived from the P1 subunit volumes (Freundt 1989) and the respective mixing proportions described next.

Rhyolite (ca. $10 \mathrm{~km}^{3}$ DRE) : crystal content increases substantially in rhyolitic tuff and inclusions from crystal-poor rhyolite of unit R1 ( 9 to 23 vol. \%) to highly phyric rhyolite ( 28 to 57 vol. \%) of units R2 to R4. We also distinguish evolved rhyolite (28 to 37 vol. \% phenocrysts) by its maximum content of incompatible trace elements. The phenocryst population is dominated ( 75 to $92 \%$ ) by mm-sized anorthoclase crystals, many containing oligoclase cores. Highly phyric rhyolite contains up to $20 \mathrm{wt} . \%$ accumulated anorthoclase, as indicated by diluted $\mathrm{Zr}, \mathrm{Nb}$ and $\mathrm{REE}$ concentrations compared to evolved rhyolite. Minor phenocrysts are edenitic amphibole and Fe-Ti oxides; accessory phases are zircon and apatite. The matrix is composed of alkali feldspar, quartz, actinolitic amphibole, and oxides. 


\section{B}
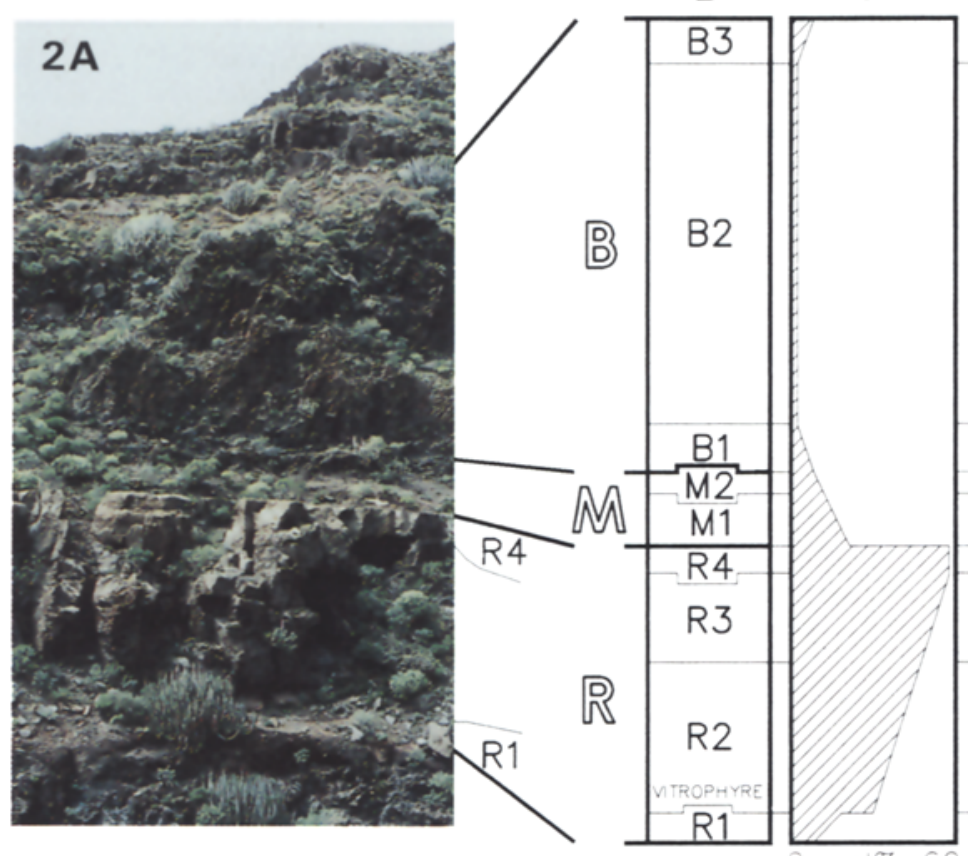

D
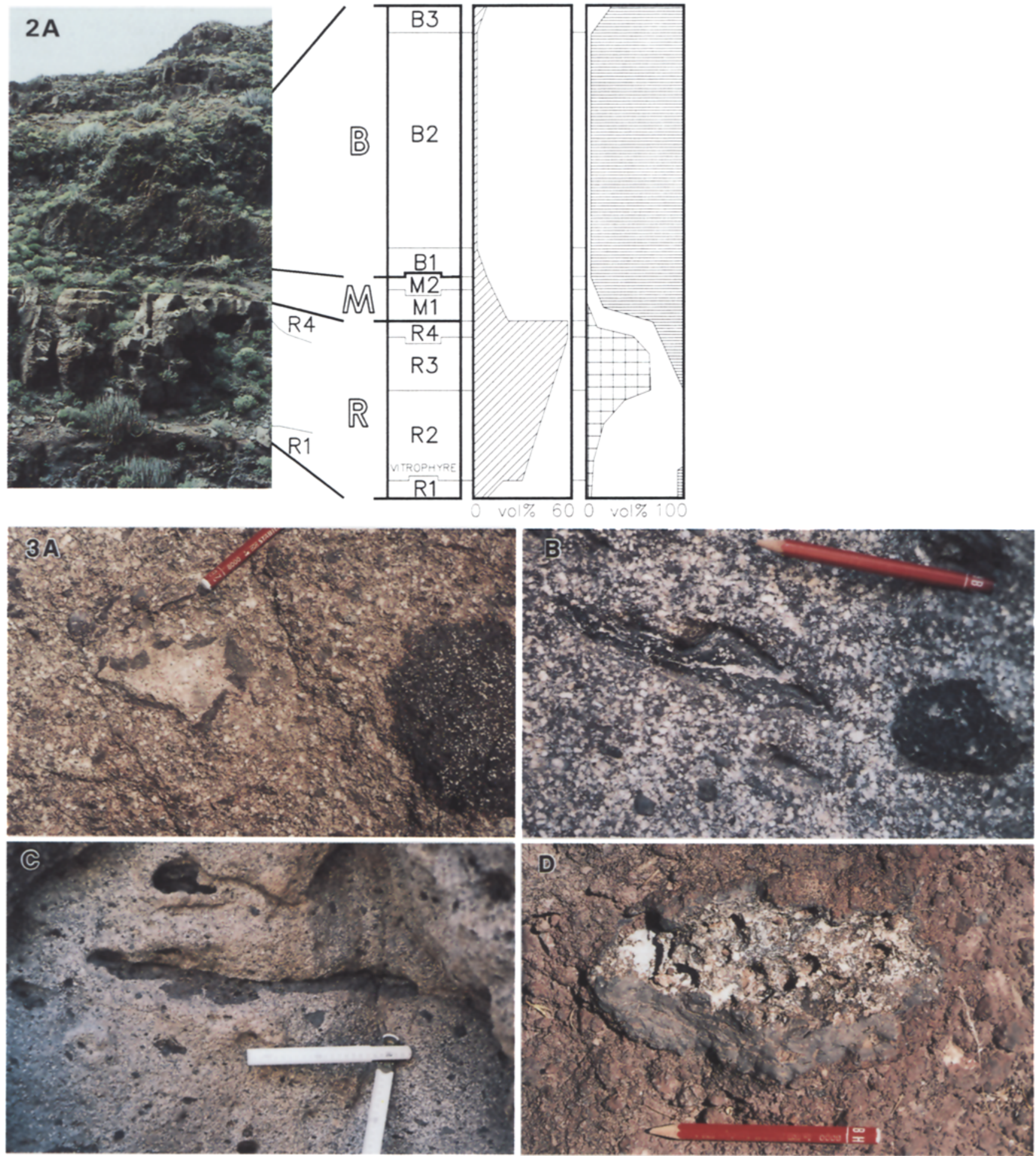

Fig. 2. A Composite flow P1 southwest of San Nicolás showing the major units rhyolite $(R)$, mixed rock $(M)$ and basalt $(B)$. Pale thickly columnar rhyolite is about $10 \mathrm{~m}$ thick. Backweathered horizons correspond to subunit R1 at the base, the mixed rock units in the middle, and B3 basalt at the top. B Stratigraphy of P1 subunits shown in approximately volume-normalized thickness scale. C Variation in anorthoclase content of the tuff. Anorthoclase content of tuff and rhyolitic fiamme covary from R1 to R4, thus reflecting changes in rhyolite magma composition rather than effects of ignimbrite transport (e.g., loss of vitric ash). D Rhyolite (blank), trachyte-trachyandesite (net hatch) and basalt (dense lining) fractions in the tuff based on the distribution of inclusions (visual field estimates). Rhyolite fiamme dominate in R1 and R2, trachyte-

trachyandesite inclusions are most abundant in $\mathrm{R} 3$, and basalt inclusions increase from $\mathrm{R} 3$ through M2 until the tuff itself is basaltic. Note the increase in rhyolite inclusions and anorthoclase crystals in B3

Fig. 3A-D. Selected inclusions in P1 tuff units. A Pale, irregularly shaped rhyolitic inclusion (center) with broken dark vesicular basalt rim, and dark trachyandesite inclusion (right) in unit R4. B Mixed inclusion of dark trachyte with pale rhyolite bands (center), and dark trachyandesite inclusion (right) in unit R2. C Large, flattened, vesicular basalt inclusion in unit R4. D Strongly inflated rhyolite inclusion rimmed with dense basalt in clastic basalt unit B3 


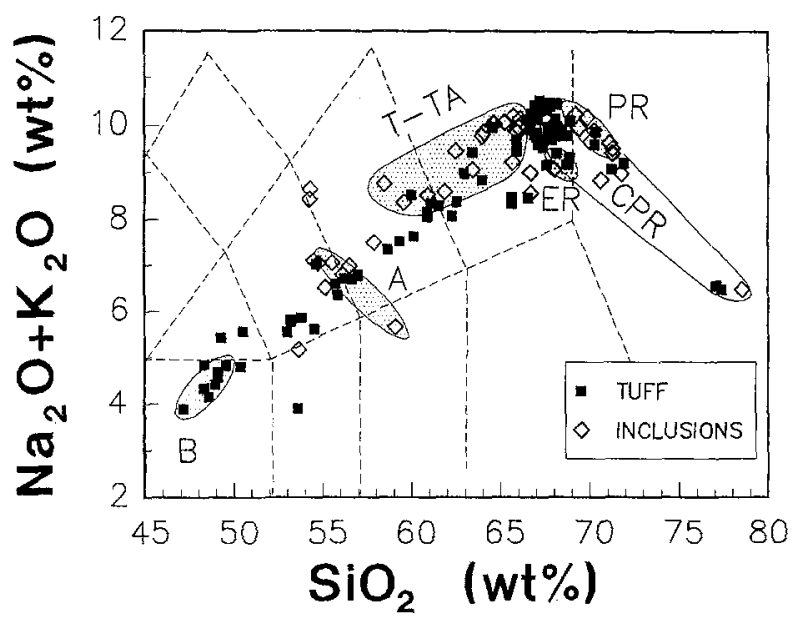

Fig. 4. Alkalis-silica variation diagram for mixed tuff and inclusions. Magmatic end-member fields based on compositionally homogeneous inclusion and tuff samples. Crystal-poor rhyolite $(C P R)$ field mainly represented by basal tuff $\mathrm{R} 1$ also includes a high-silica variety of deuterically silicified rock. $P R$ : highly phyric rhyolite; $E R$ : evolved rhyolite; $T-T A$ : trachyte - sodic trachyandesite; $A$ : andesite and sodium-poor trachyandesite; $B$ : basalt. Grid after Le Maitre et al. (1989)

Trachyte to sodic trachyandesite (ca. $6 \mathrm{~km}^{3} \mathrm{DRE}$ ): these inclusions form a continuous group ranging from 58 to $66 \mathrm{wt} \% \mathrm{SiO}_{2}$. The phenocryst fraction (18 to $35 \%$ ) is dominated by oligoclase and comprises minor augite, orthopyroxene, Fe-Ti oxides and accessory apatite. Both relatively homogeneous and strongly zoned oligoclase crystals cover the range $A n=4$ to 30 . Their Or-content is lower than that of the oligoclase cores in rhyolitic anorthoclase phenocrysts. The oligoclase/augite-ratio and the size of the oligoclase crystals increase towards the chemically more evolved rocks, in which many oligoclase crystals exhibit characteristic coarse sievetextured rims. Matrix phases are alkali feldspar, richteritic amphibole, silica phases, and oxides. Richteritic amphibole replaced augite during late-stage intratelluric crystallization.

Andesite to sodium-poor trachyandesite (subordinate volume, $<1 \mathrm{~km}^{3}$ DRE): the mineralogical composition of these inclusions, with andesine, augite, hypersthene, Fe-Ti oxides and apatite, is similar to the sodic trachyandesite inclusions. The andesitic to trachyandesitic rocks differ, however, in mineral compositions as well as in bulk rock composition ( 55.5 to $59 \mathrm{wt} . \% \mathrm{SiO}_{2}$ ) and are ca. 2 wt.\% less sodic (Freundt and Schmincke submitted).

Basalt (ca. $26 \mathrm{~km}^{3}$ DRE): the basalt (47.2 to 49.5 wt. $\% \mathrm{SiO}_{2}$ ) is nearly aphyric with less than $2 \%$ phenocrysts of calcic plagioclase, diopside, Fe-Ti oxides and olivine as well as accessory apatite. All olivine is altered to red iddingsite. Phenocryst abundance and size, the fraction of olivine, and bulk $\mathrm{MgO}$-content (4.3 to 5.2 wt. \%) increase from unit B1 to B3. The matrix consists largely of plagioclase, augite and oxides, but equant red-orange iddingsitized olivine increases stratigraphically upwards.

\section{Physically mixed tuff and inclusions}

\section{Mixing textures in the tuff}

Rhyolitic glass shards are well preserved in the poorly welded basal unit $R 1$ and in the vitrophyre, where fiamme increase upwards in size and abundance. Rare elongate, strongly distorted, black tachylitic basalt inclu- sions of low porosity are aligned parallel to collapsed pumice and matrix lineation. The eutaxitic texture of the vitrophyre is pronounced where it is composed of both pale rhyolitic and brown trachytic fiamme (Fig. 5A).

The matrix of unit $R 2$ consists of extremely stretched and distorted darker microcrystalline threads that alternate with pale, stretched lenses of more coarsely crystallized rhyolite matrix (Fig. 5B). The matrix of the nonvesicular trachyte inclusions is dark and microcrystalline whereas rhyolite inclusions are coarsely crystalline. Both rhyolite and trachyte inclusions are intimately mingled with the matrix; streaks are torn off their surface and taper into thin threads extending into the tuff matrix. Locally, darker trachytic threads in the R2 matrix can be identified from their phenocrysts, but since textures as in Fig. 5B are also common in purely rhyolitic ignimbrites they can be mainly attributed to crystallization in response to pre-welding grain size differences (e.g., Ross and Smith 1961).

The tuff matrix of unit $R 3$ is very heterogeneous with a significant fraction of intermingled darker trachyte streaks. Though dense, spherulitic trachyte inclusions still dominate, a range of variably vesicular inclusions can be observed and pumiceous trachyte and sodic trachyandesite inclusions with well-preserved vesicular structure and quenched denser margins are also common (Fig. 5C). Trachytic inclusions diminish in abundance across the R3/R4 boundary, and basaltic inclusions increase in number, size, and vesicularity, many of them being pumiceous.

The basalt inclusions in unit $R 4$ are intensely mixed in a kind of emulsion texture with the rhyolite matrix (Fig. 5D). They form flattened or very frail, thin, crenulate bodies ranging from densely chilled to pumiceous that were obviously deformed in a viscous state. Pillowlike structures with chilled margins and vesicular interior are observed (Fig. 5D). Small angular to crenulate chips of basalt probably represent fragmented basalt inclusions. Rhyolitic and trachytic minerals are rare in the basalt inclusions but, where present, often show features of disintegration (oxidation, resorption) in contrast to corresponding minerals in the rhyolitic host tuff. This is probably due largely to the compositional contrast, but it could also reflect entrainment of crystals into basalt prior to its admixture with the present host rhyolite. The homogeneous crystallization of the R4 rhyolite matrix (Fig. 5D) can be attributed to both slower cooling near the center of the cooling unit and higher initial heat input from the admixed basalt.

The proportion of basalt inclusions increases greatly in unit M1 (Fig. 2). While most basalt inclusions have a black tachylitic matrix, larger basalt inclusions are hyalopilitic with abundant skeletal plagioclase microlites. The mean size of basaltic inclusions is significantly smaller in M1 than in R4 due to the abundance of crenulate or angular bits in the 100 to $300 \mu \mathrm{m}$ size range, which appear to be fragments of vesicular basalt inclusions, partly broken up in a viscous state (Fig. 5E). Large rhyolitic inclusions in M1 contain large round vesicles in homogeneously crystallized matrix. 

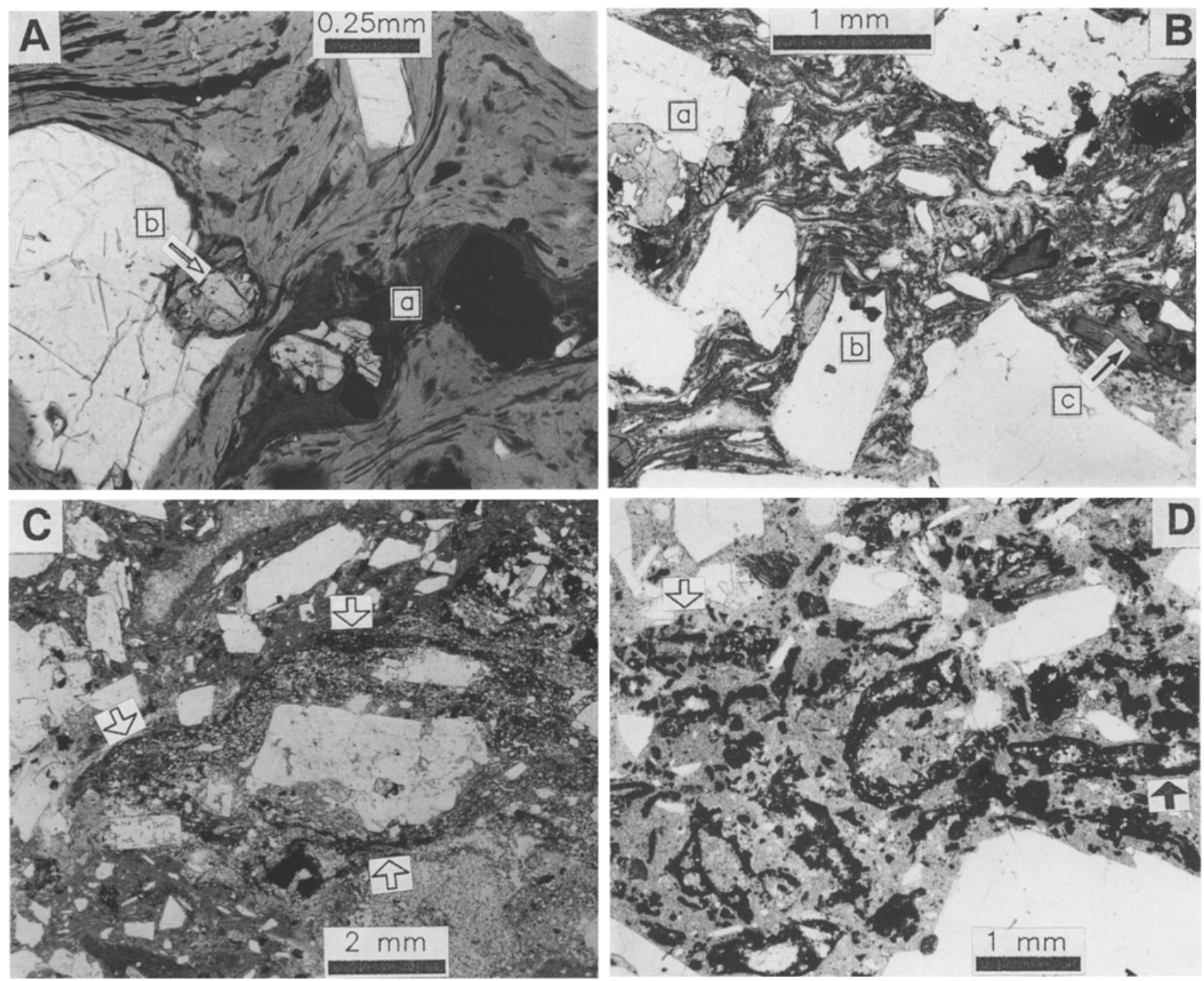

Fig. 5A-E. Mixed tuff. A Eutaxitic vitrophyre of pale rhyolitic glass with dark streaks of trachytic glass. (a) Trachyte fiamme containing augite and Fe-Ti-oxide phenocrysts. (b) Pale augite (arrow) included in darker edenite marginally intergrown with anorthoclase. B Flow-banded rhyolitic R2 tuff matrix consisting of microcrystalline (dark) and coarser crystallized (pale) streaks intensely folded and compressed near crystal edges. (a) Trachyte-derived oligoclase with marginally intergrown augite. (b) Rhyolite-derived anorthoclase with marginally intergrown edenite. (c) Edenite (dark) with augite inclusion (pale, arrow) showing rhyolite-trachyte mixing during crystallization. C Finely vesicular flattened trachyte inclusion in R3 with thin dark chilled margins (arrows). Round shape of most tiny vesicles may suggest post-compactional degassing. D Vesicular tachylitic basalt inclusions in rhyolitic R4 matrix. Fragile crenulate inclusions have vesicles concentrated near center ("pillows", black arrow) and smaller angular inclusions are mostly "pillow"-fragments (white arrow). The homogeneously microcrystalline rhyolitic matrix no longer shows a particulate or subparallel texture. E Higher fraction of significantly smaller, often angular and less vesicular fragmented basalt inclusions in M1 compared to R4. Edenite is marginally oxidized (white arrow) to strongly

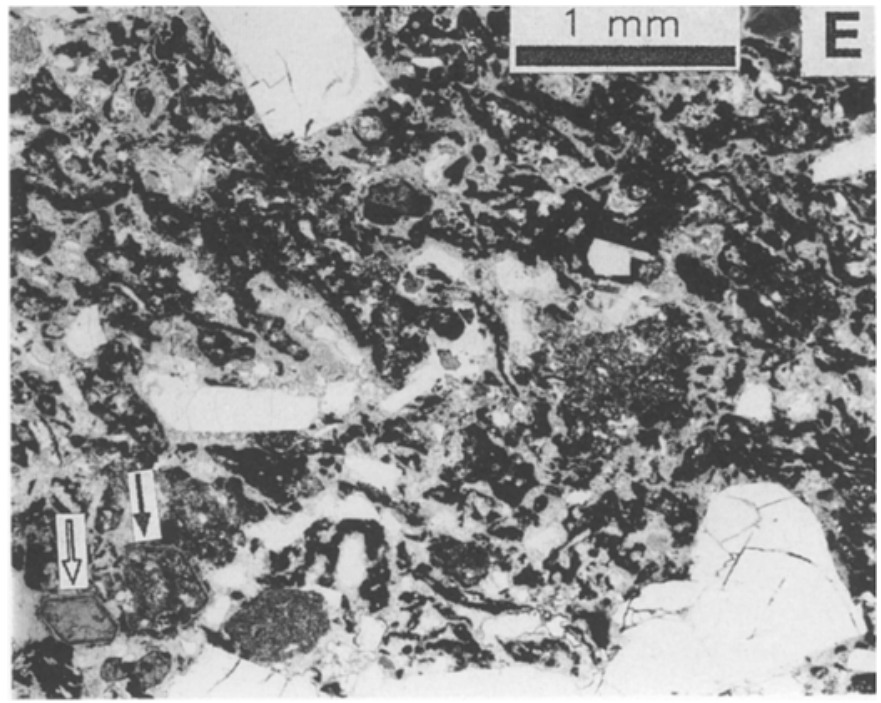
altered (black arrow) 


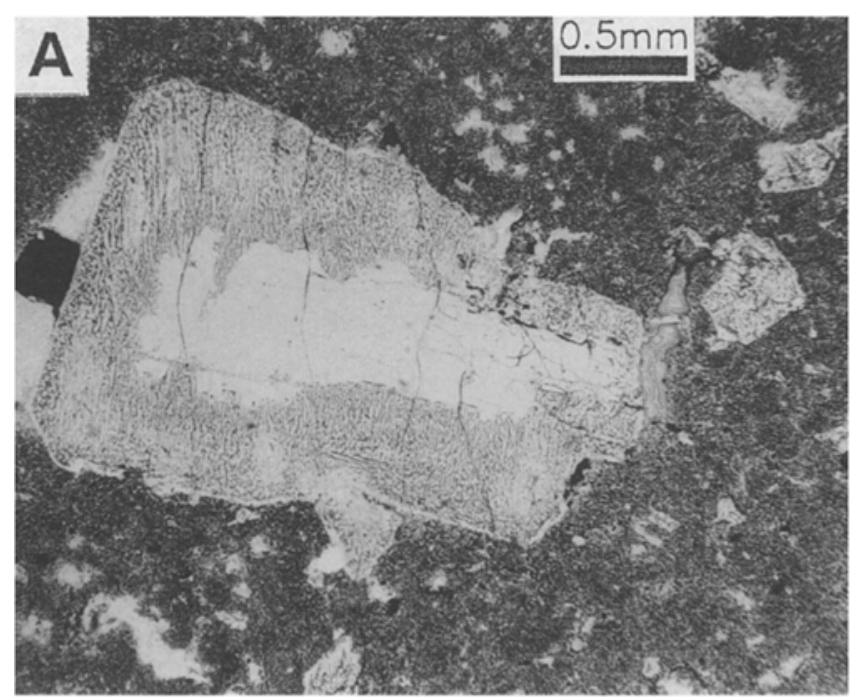

Fig. 6. A Anorthoclase crystal with marginal fingerprint resorption texture in B1 basaltic matrix. Crystals smaller than the width of the resorption zone are entirely resorbed (e.g., upper right corner). B Extremely inflated "reticulitic" rhyolite inclusion in basalt tuff

The interstitial rhyolite matrix in unit $M 2$ is more coarsely and inhomogeneously crystallized than in M1. The proportion of basalt is slightly higher (Fig. 2), and diffuse dark zones of microcrystalline basaltic matrix occur next to the well-defined basaltic inclusions. Mainly rhyolite-derived, partly trachyte-derived sodic feldspar crystals in the mixed rock have marginal zones, $<100 \mu \mathrm{m}$ wide, of fingerprint resorption texture.

Fingerprint resorption zones of incorporated feldspar crystals in the basaltic tuff increase in width from the mixed rock to basalt unit B1, where they are ca. 300 $400 \mu \mathrm{m}$ wide (Fig. 6A) and many crystals are completely covered. In unit B2, sodic feldspar crystals are completely resorbed and disintegrated to isolated speckles. In the poorly to nonwelded top-unit B3, however, sodic feldspars are not or only very marginally affected by resorption. Distorted and highly inflated rhyolitic inclusions are rare in the basaltic tuff; a plausible cause is that their "reticulitic" matrix (Fig. 6B) was rapidly destroyed during transport, leaving isolated phenocrysts in the basaltic host where they became resorbed and disintegrated.

\section{Mixing textures of inclusions}

Large mixed inclusions from P1 provide a slightly largerscale view into mixing textures than does the P1 tuff, where the mixed magma was intensely fragmented. Selected mixed inclusions are now described in order to reveal mixing processes active prior to fragmentation.

Rhyolite - trachyte mixed inchisions. In a banded inclusion from the base of unit R3 (\# 405, Fig. 9), bands of variable thickness $(<100 \mu \mathrm{m}$ to several $\mathrm{mm}$ ) of pure rhyolite and trachyte composition are intimately mingled

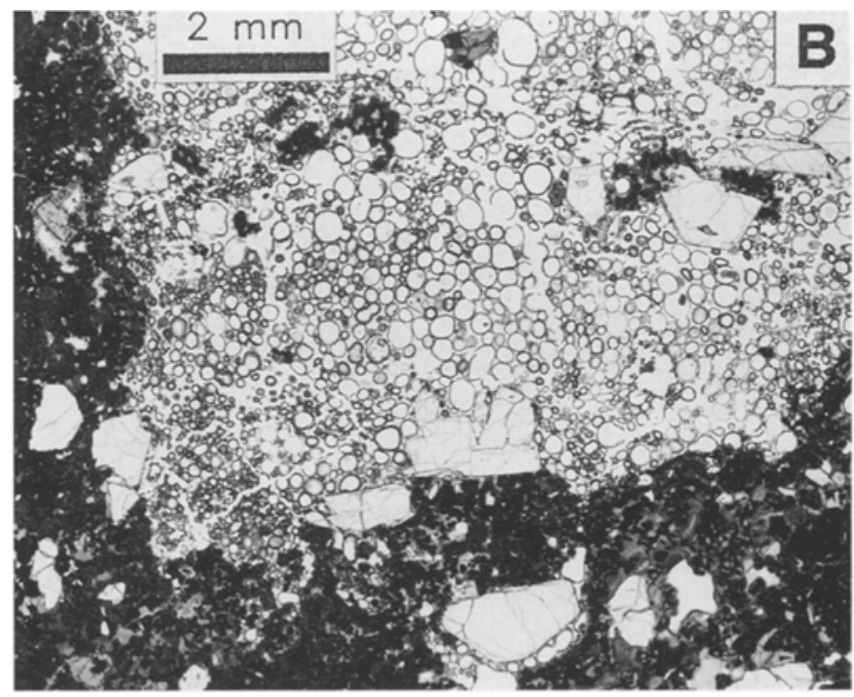

B3, consisting of bubble walls only. Anorthoclase crystal at bottom center had adhering bubble-wall glass, whereas other anorthoclase fragments have lost such glass

(Fig. 7A). This intimate mixing and the absence of chilled margins argue against a major temperature contrast although the rhyolite matrix is more coarsely crystallized than the dark trachyte matrix. The almost identical deformation patterns of rhyolite and trachyte also indicate very similar viscosities of the respective melts during mixing.

A particular banded inclusion from R2 (\#212, Fig. 9) with fine-grained, bimodal, streaky to mottled flow-textured matrix contains mixed phenocryst populations from rhyolite and evolved trachyte, characterized by abundant large, sieve-textured oligoclase crystals (Freundt and Schmincke submitted). The intimately mixed matrix contains strongly deformed, devitrified lenses of sodic trachyandesite (Fig. 7B), which are characterized by smaller, stubby, euhedral, well-twinned oligoclase phenocrysts and differ from Na-poor trachyandesite/andesite by containing late richteritic amphibole. These relationships show that mixing of rhyolite with evolved trachyte magma was more intense than with sodic trachyandesite magma.

Most of the rhyolite/trachyte mixed inclusions have a mixed mineralogy but a matrix that is heterogeneous on a very small scale compared to the banded inclusions. In rhyolite-dominated inclusions (e.g., \# 728, \#117 in Fig. 9), the matrix is more coarsely crystallized; in trachyte-dominated inclusions (e.g., \#753 in Fig. 9) it is microcrystalline; and in intermediate inclusions (e.g., \#741, \#212 in Fig. 9) the matrix has a mottled texture. In trachyte-dominated samples, an overgrowth of late trachyte richterite on rhyolite edenite phenocrysts occurs, and, very rarely, thin resorbed margins formed on anorthoclase crystals. In one example (\#753, Fig. 9) of a trachyte-dominated inclusion, the microcrystalline matrix appears to be homogeneous except for very subtle banding reflected mainly by variations in the high porosity. Matrix and pore phase amphiboles, however, plot 

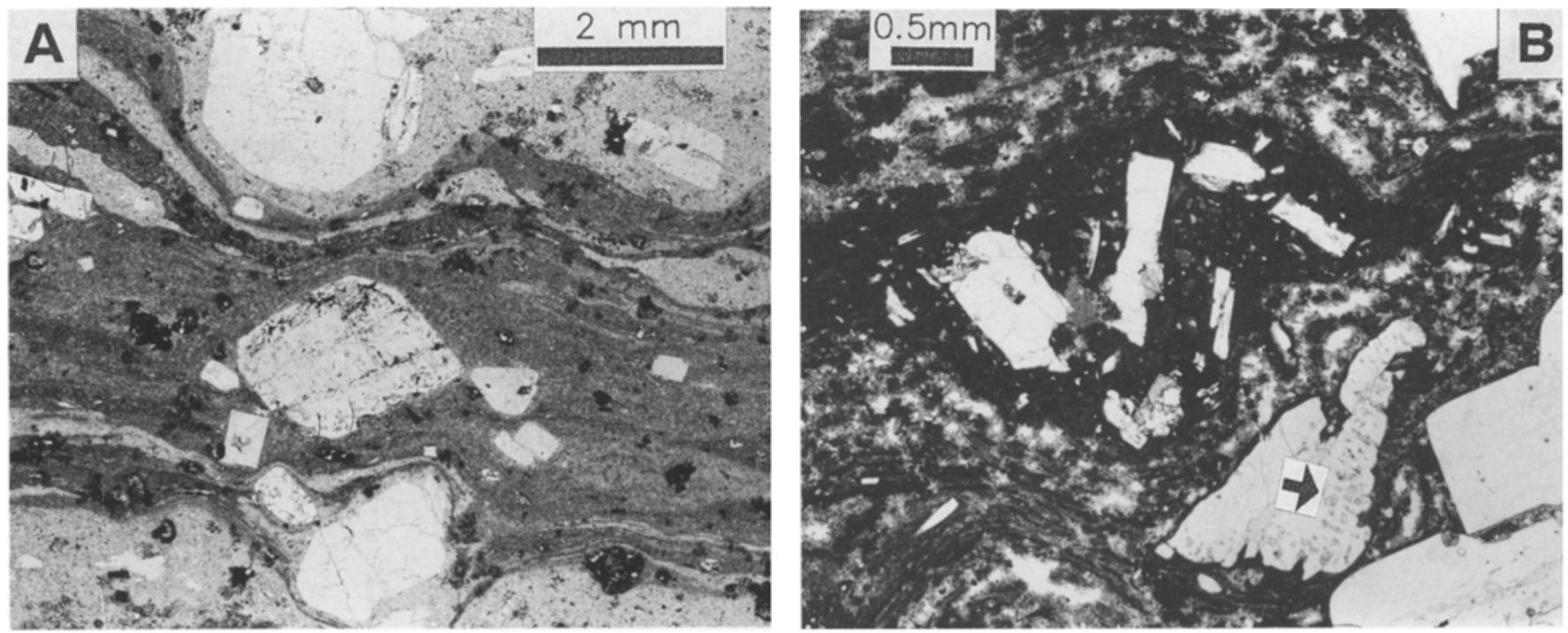

Fig. 7 A-C. Mixed inclusions. A Banded inclusion showing intimate mixing of dark, microcrystalline trachyte with pale, coarser crystallized rhyolite (\# 405, Fig. 9). B Dark distorted sodic trachyandesite inclusion with stubby euhedral oligoclase phenocrysts, included in mottled matrix of mixed rhyolite and evolved trachyte characterized by sieve-textured larger oligoclase (arrow) (\#212, Fig. 9). C Basalt-rhyolite mixed inclusion from unit B3 (\#1020, Fig. 9). Light-colored matrix $(a)$ is basalt-rhyolite hybrid, in disequilibrium with marginally resorbed anorthoclase, and sufficiently anhydrous to stabilize clinopyroxene instead of amphibole. Basalt inclusions comprise mainly the quenched tachylitic emulsion-texture type $(b)$, a microcrystalline type ( $c$, dark lower right sector), and a fully crystallized type (not shown). All inclusions show signs of fragmentation; e.g., feldspar broken off at surface $(d)$

on a mixing line between richteritic and actinolitic compositions, indicating very local control of trachyte through hybrid to rhyolite composition on matrix and pore phase crystallization.

Basalt - rhyolite/trachyte mixed inclusions. Inclusions in which basalt forms the minor component (e.g., \#811, \#1492b in Fig. 9) texturally resemble tuff unit R4: amoeboidally shaped, dense to vesicular, black basalt inclusions form an emulsion texture in phyric rhyolite (plus trachyte) with homogeneously crystallized, vesicular matrix. It is interesting to note that the basalt particles in these inclusions are not obviously larger than those in R4 tuff, which suggests that most of the basalt fragmented in the magma chamber or conduit before pyroclastic fragmentation in the vent.

In basalt-dominated inclusions, the homogeneous matrix is basaltic (e.g., \#118 in Fig. 9), just as in the welded basaltic tuff (e.g., unit B1; Fig. 6A). In this case, mixing in the liquid state had already reached such a

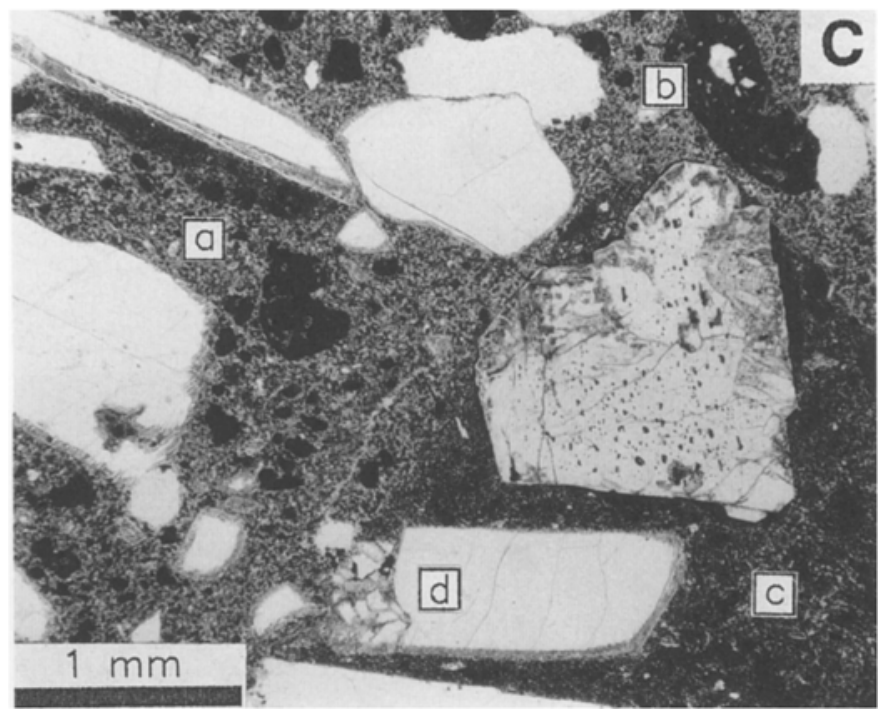

high degree of homogenization that pyroclastic fragmentation was unable to further reduce the length-scale of heterogeneities.

A special group of pale mixed inclusions is abundant in unit B3 and appears to reflect mixing during the terminal phase of eruption. These inclusions (\# 514, \#518, \#1020 in Fig. 9) contain variable amounts of rhyolite/ trachyte-derived crystals as well as three types of basaltic bodies:

1. Mainly quenched emulsion-texture type of basalt and fragments thereof (Fig. 7C)

2. Less common fragments of microcrystalline basalt containing anorthoclase crystals (Fig. 7C)

3. And fully crystallized oval basalt bodies containing cumulate fragments or sodic feldspar with resorption rim.

The matrix of the mixed inclusions is hyalopilitic with yellow devitrified glass, feldspar, clinopyroxene and opaque oxides. We interpret this matrix as a basalt-rhyolite hybrid, because (a) it contains clinopyroxene rather than amphibole (as does R4 with a similar fraction of 
included basalt), and (b) it is in disequilibrium with the marginally resorbed sodic feldspars.

These complex rhyolite-hybrid-basalt inclusions are associated with an increased number of subvolcanic lithics in unit B3 and are probably derived from the conduit, which partially collapsed or widened in the course of $\mathrm{B} 3$ eruption. We envisage partial hybridization of a new surge of B3 basalt magma with superheated rhyolite magma that probably resided near the conduit entrance and was already rich in emulsion-type tachylitic basalt inclusions. This mixture incorporated fragments of basalt from earlier (B1-B2) phases of eruption that was chilled at the conduit walls.

\section{Component proportions in tuff profiles and mixed inclusions}

We have analyzed major and trace element concentrations of bulk tuff and inclusion samples from stratigraphically correlated P1 profiles all around the island in order to determine proportions of the component magmas (a data table is available from the authors on request). The $\mathrm{Nb}-\mathrm{Ba}$ diagram (Fig. $8 \mathrm{a}$ ) is a convenient quantitative approach to evaluate proportions because the three main end-member fields are well separated. The andesitic to Na-poor trachyandesitic end-member inclusions fall on the basalt-rhyolite tie-line (Fig. 8a). Their involvement in the mixed compositions cannot be quantified from Fig. 8 but is minimal, as suggested by petrographic and other chemical data.

The general trend of tuff composition starts with a rhyolitic composition at the base of $\mathrm{P} 1$, with trachyte increasing in proportion upward and eventually reaching $70 \%$ in R3. From here on, the basalt fraction becomes significant and increases continuously while the trachyte fraction diminishes to a $1: 2$ trachyte to rhyolite ratio (Fig. $8 \mathrm{a}, \mathrm{b}$ ). Note how the trachyte-rich peak of the compositional trend points to the top of the trachyte field (Fig. 8a), implying that the fraction of Nb-rich evolved trachyte in the mixed tuff is much greater than the fraction of $\mathrm{Nb}$-poor sodic trachyandesite. The vertical nonuniformity and regional variability of tuff composition trends is emphasized in Fig. $8 \mathrm{c}$, where the stratigraphic variations in $\mathrm{Nb}$ and $\mathrm{Ba}$ concentrations are shown for 5 selected profiles from northwest, west and southwest of the caldera. Most profiles exhibit an unsteady pattern implying that the mixing process was also unsteady and involved minor recurrences. The peak trachyte content, the stratigraphic level where it occurs, and the associated basalt fraction vary slightly between sectors. Striking field examples of such sectorial changes are the occurrence of $30 \%$ trachyte inclusions at the base of $\mathrm{P} 1$ at $M$. Hogarzales in the west and the large trachyte inclusions in B3 basalt at Miraflor in the northeast, as noted already.

Inclusions with mixed matrix and mineral assemblages are scattered throughout the $\mathrm{Nb}$ - $\mathrm{Ba}$ mixing ternary (Fig. 9); those falling below the B-T sideline near the trachyte-rich end are mixtures with low- $\mathrm{Nb}$ trachyandesite rather than with high- $\mathrm{Nb}$ trachyte. Inclusions from units R1 through R 3 remain below $30 \%$ basalt and scatter between rhyolite and trachyte end-members; those from unit R4 reach $60 \%$ basalt. Inclusions from the mixed rock and the basalt zones of P1 span the entire range of basalt fractions; some are identical in composi-
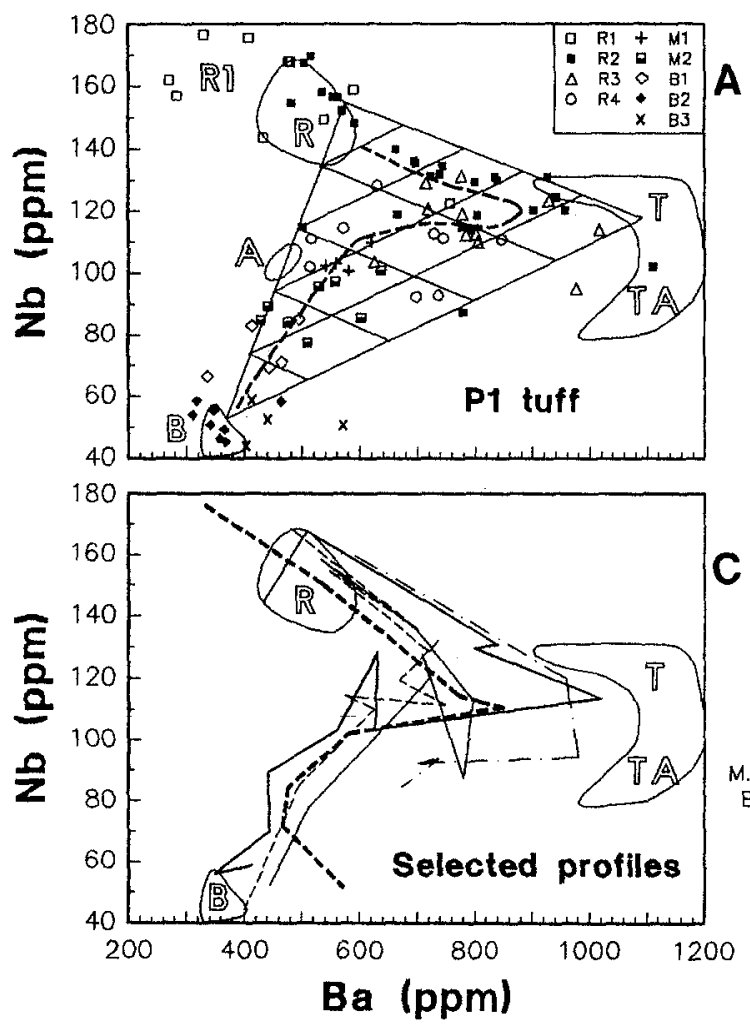

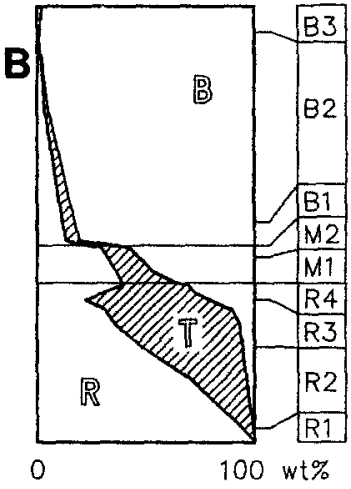

Magma fractions

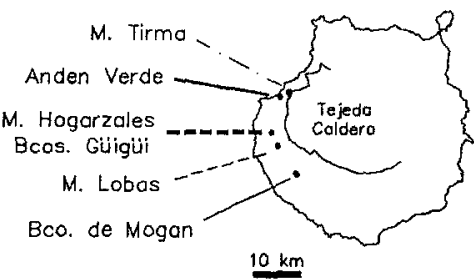

Fig. 8A-C. $\mathrm{Nb}$ versus $\mathrm{Ba}$ variation for P1 tuff. The sharp corners of the triangular mixing grid are an oversimplification considering end-member compositional zonations. $R$ : rhyolite; $T$ : trachyte; $T A$ : sodic trachyandesite; $A$ : Napoor (trachy)andesite; $B$ : basalt. $\mathbf{A}$ Dashed line shows an average mixing trend on which the vertical variation in magma fractions in $\mathbf{B}$ is based. Na-poor trachyandesite inclusions $(A)$ plot on the rhyolite-basalt mixing line. Their role in the mixing thus cannot be assessed but this component is unimportant in terms of volume. Crystal-poor R1 shifted from $\mathrm{R}$-field to higher $\mathrm{Nb}$ and lower $\mathrm{Ba}$ by anorthoclase fractionation. C Shows the base (at $R$ ) to top (at $B$ ) variation in P1 profiles from NW to $\mathrm{SW}$ around the caldera sampled in most detail 


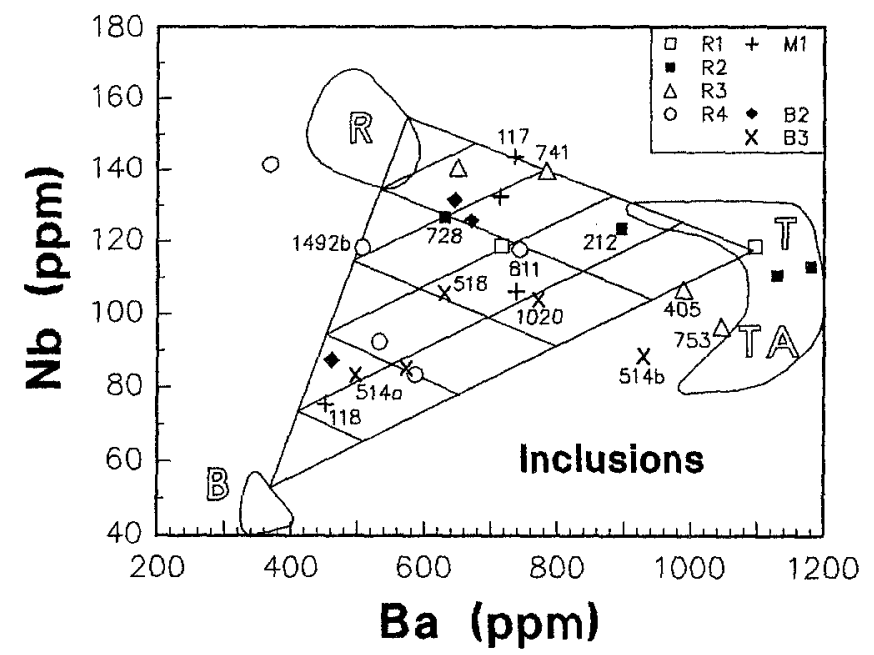

Fig. 9. Mixed inclusions in P1 show the same overall Nb-Ba variation as bulk P1 tuff, but within-unit variations differ as discussed in the text. Symbols in inset distinguish the P1 subunits from which inclusions were collected. Samples plotting below the right corner of the grid contain large fractions of sodic trachyandesite $(T A)$

tion to their host tuff while others represent more felsic or, in the mixed rock, also more basaltic components.

\section{Syneruptive magma mixing}

We consider all mixed rocks showing evidence for mechanical mixing but lacking evidence for efficient diffusive homogenization to have mixed during eruption. This would exclude the basalt-dominated basalt-rhyolite mixtures, as the strong resorption of anorthoclase crystals in basaltic tuff (Fig. 6A), and the assimilation of the rhyolite matrix stripped from them, certainly involved efficient chemical diffusion. The width of the fingerprint resorption zones does, however, increase with the basalt fraction from units M1 through B2, which is densely welded. In poorly welded to nonwelded B3 at the top of P1, the rims are very thin or absent. Fingerprint resorption of anorthoclase crystals is, thus, clearly correlated with emplacement temperature and duration of cooling. Therefore, resorption occurred mainly after emplacement and basalt-rhyolite mixing must also be considered a syn-eruptive process, even though chemical diffusion played a major role in hybridization.

Syn-eruptive mixing would include simultaneous withdrawal of different magmas from the reservoir, their ascent through the conduit, and their fragmentation and particulate transport out of the vent and across the land surface. Comparing tuff and inclusion data for units R2 and $\mathrm{R} 3$, we find numerous tuff compositions in the range 20 to $40 \%$ rhyolite with $<20 \%$ basalt (Fig. 8 a), but mixed inclusions in this compositional range are scarce, concentrating instead either closer to the rhyolite or to the trachyte field (Fig. 9). Tuff composition of unit M1 is restricted to around 40 to $50 \%$ basalt and $40 \%$ rhyolite (Fig. 8a), whereas M1 inclusions scatter from 0 to $80 \%$ basalt (Fig. 9). We interpret these compositional differences as an effect of fragmentation. Inclusions re- present a state of mixing before fragmentation when heterogeneities existed which were larger than the inclusions, so that an inclusion cannot reflect the bulk composition of the mixture from which it was derived. Fragmentation of the mixed-magma assemblage reduced the size of heterogeneities well below that of the tuff samples analyzed, so that these better represent the bulk composition of the mixture. We believe that proportions of the component magmas are determined by processes active both in the chamber and in the conduit. Density segregation during particulate transport over long distances in the atmosphere might cause modification of component proportions in Plinian fallout deposits, but we did not find convincing evidence for such segregation during pyroclastic-flow transport of P1. Fragmentation, transport and welding significantly modified mixing structures but not compositions.

The composition of the magma mixture erupting changed systematically with time. Rhyolite magma was discharged during the early phase of eruption, starting with crystal-poor rhyolite (unit R1) but rapidly changing to increasingly phyric rhyolite (from R2 on). Trachyte to sodic trachyandesite magma gradually joined the rhyolite and dominated the bulk composition during eruption of unit R3 (Fig. 8 b). The trachyte fraction decreased drastically from R4 onwards, whereas the basalt fraction increased strongly from R3 through M2, finally reaching $>95 \%$ in the basalt units (Fig. $8 \mathrm{~b}$ ). These proportions were governed by withdrawal of magmas from the reservoir into the conduit. We interpret sectorial changes in the vertical evolution of component fractions (e.g., level of onset and maximum fraction of trachyte) as a result of varying geometric configuration along the entrance of a fissure-shaped conduit. The sectorial differences argue strongly for eruption through a ringfissure system rather than a central vent, and this is supported by the absence of fallout deposits in P1. The actual source of the P1 eruption is, however, unknown although P1 is exposed at the Tejeda caldera rim at several localities, because the presently exposed rim has been modified by Miocene volcanic, tectonic and erosional activity post-dating the $\mathrm{P} 1$ eruption and intra-caldera P1 is totally covered by younger rocks.

\section{Mutual inclusions of phenocryst phases}

Phenocrysts indigenous to trachyte inclusions contain phases derived from rhyolitic magma and vice versa in rhyolite inclusions. In trachytic rocks, edenite and minor zircon, oxides, and apatite occur within oligoclase phenocrysts (Fig. 10A), while in rhyolitic rocks augite, minor oxides, and apatite occur within edenite (Fig. 5B). A special case is shown in Fig. $10 \mathrm{~B}$, where edenite containing an augite core is mantled by richteritic amphibole in a trachyte-dominated mixed inclusion (\#753, Fig. 9). This documents two mixing events: (1) initial admixing of a trachyte magma batch into rhyolite magma, followed by (2) admixing of this rhyolite batch into trachyte magma; the two events are separated by the duration of edenite overgrowth. 


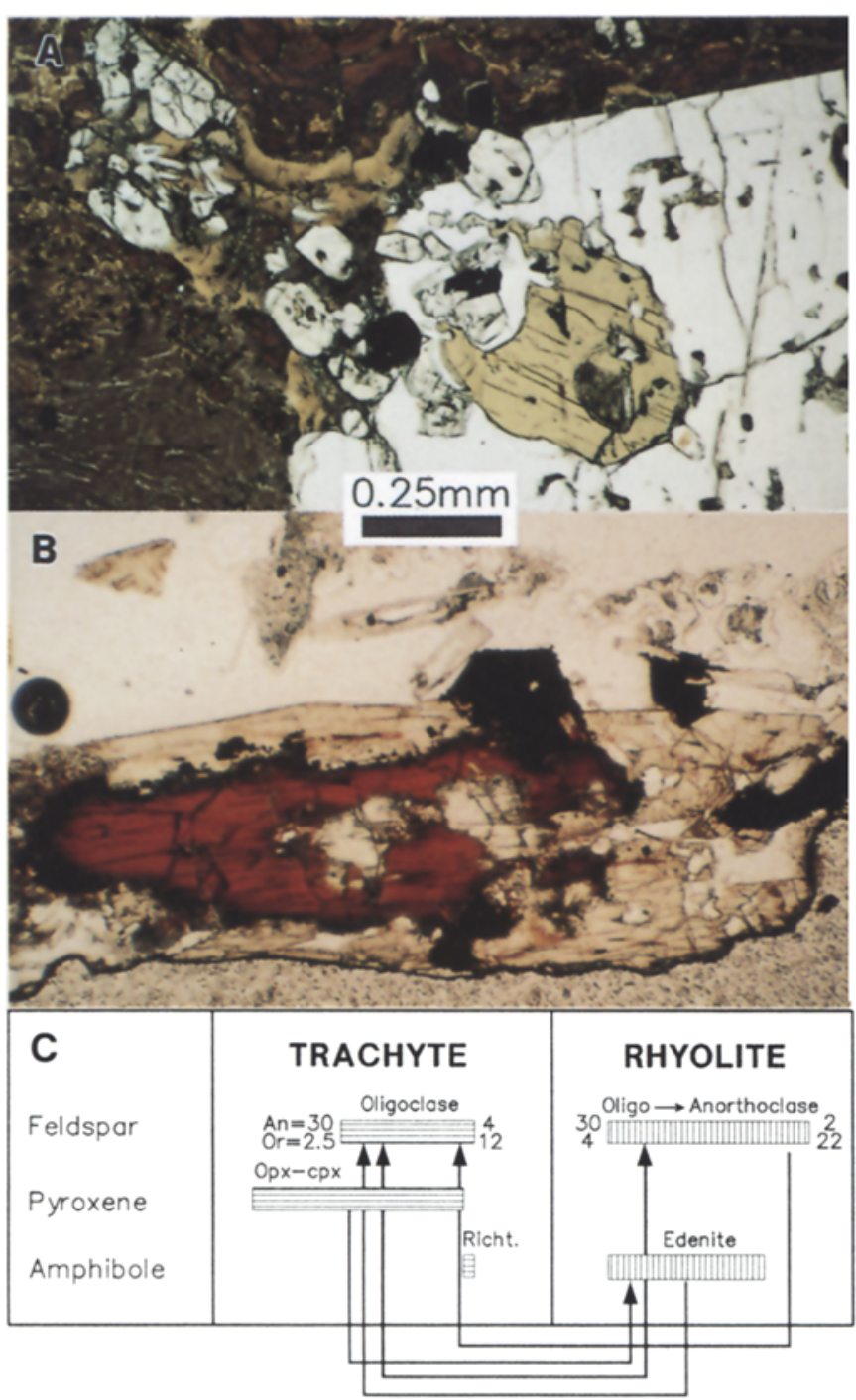

Fig. 10. A Rhyolite-derived edenitic amphibole (green-brown) included in typically sieve-textured trachyte oligoclase associated with augite microphenocrysts (light-green), in brown trachytic glass matrix. B Pale trachyte-derived augite core in red-brown (oxidized) edenite mantled by pale-yellow richterite in trachyte-rhyolite mixed inclusion (\#753, Fig. 9). C Schematic summary of mutual mineral inclusion relationships due to rhyolite-trachyte mixing during crystallization. Bars indicate sequence of crystallization from left to right

Rhyolite feldspar phenocrysts are often zoned from oligoclase cores $\left(\mathrm{An}_{30} \mathrm{Or}_{4}\right)$ to anorthoclase mantles $\left(\mathrm{An}_{2} \mathrm{Or}_{22}\right)$ but the oligoclase cores are distinctly more Or-rich than trachyte oligoclase phenocrysts $\left(\mathrm{An}_{30} \mathrm{Or}_{2.5}\right.$ to $\mathrm{An}_{4} \mathrm{Or}_{12}$; Fig. 10C). Low-Or oligoclase cores, or compositional zones within these cores that could be interpreted as trachyte-derived are extremely rare. Trachytic rocks, on the other hand, do contain rhyolitederived feldspar crystals. They also contain zoned feldspar phenocrysts showing various zonation patterns: (a) high-Or oligoclase composition $\left(\mathrm{An}_{22} \mathrm{Or}_{5.5}\right)$ at the center changing to low-Or composition towards the rim $\left(\mathrm{An}_{20} \mathrm{Or}_{3.5}\right)$, (b) a high-Or compositional zone $\left(\mathrm{An}_{8} \mathrm{Or}_{15}\right)$ within a low-Or oligoclase crystal $\left(\mathrm{An}_{6} \mathrm{Or}_{11}\right)$, and (c) an anorthoclase core $\left(\mathrm{An}_{4} \mathrm{Or}_{17}\right)$ overgrown by
low-Or oligoclase $\left(\mathrm{An}_{6} \mathrm{Or}_{9}\right)$. A detailed account of feldspar compositions and zonations is presented elsewhere (Freundt and Schmincke submitted). Since decreasing An-content roughly defines the order of feldspar crystallization, the three feldspar zonation patterns are interpreted, respectively, as (a) admixing of rhyolite to trachyte during an early stage of crystallization, (b) transport of a crystal or magma batch from trachyte to rhyolite and back into trachyte magma, and (c) admixing of rhyolite to trachyte during a late stage of crystallization (Fig. 10 C).

\section{Magma mixing during crystallization}

Mutual mineral inclusions document mixing of rhyolite and trachyte magmas during their crystallization. The homogeneous matrix composition of end-member trachyte and rhyolite inclusions shows that complete hybridization was achieved except for the mineral inclusions. It was mainly evolved trachyte that took part in the mixing, although we occasionally also found edenite crystals in sodic trachyandesitic rocks.

The mutual inclusion relationships are summarized in Fig. 10C. Included ferromagnesian phases mainly reflect mixing events during early crystallization stages, but some examples took place during late stages (e.g., edenite in richterite; Fig. 10B). Feldspar zonations and inclusions indicate repeated mixing between trachyte and rhyolite during almost their entire crystallization interval. However, as anorthoclase represents as much as $92 \%$ of the phenocryst fraction in highly phyric rhyolite, one would expect to find anorthoclase crystals about 20 times as abundant as edenite crystals in trachyterhyolite mixtures. Despite extensive microprobe measurements, we found much less (mostly $<5 \times$ ) though the exact ratio cannot be quantified. This suggests that mixing was more efficient during early stages of crystallization when anorthoclase was not yet as abundant as now found in rhyolite rocks. We speculate that massive anorthoclase precipitation over a narrow temperature interval (compare Whitney 1988) and gravitational accumulation drastically increased the viscosity of rhyolite magma and hindered further mixing.

As most trachyte rocks contain traces of edenite and zircon derived from rhyolite, there was very little pure trachyte magma. The majority of rhyolite inclusions fiamme analyzed, on the other hand, did not show evidence for admixed trachyte. This can be attributed to: (a) a rhyolite magma volume exceeding that of trachyte magma (i.e., a volume ratio larger than that erupted: $10 \mathrm{~km}^{3}: 6 \mathrm{~km}^{3}$ ); (b) a geometric configuration where "mixing depth" almost equals magma depth of the trachyte but is much smaller than magma depth of the rhyolite; and (c) higher viscosity of the crystal-rich rhyolite reducing "mixing depth" within that magma body.

\section{Physical conditions of mixing}

We investigated the physical state of the magmas and the zonation pattern of the reservoir as the physical framework for magma mixing. Mineral thermometry 
Table 2. Temperature, pressure and water content of end-member magmas

\begin{tabular}{llll}
\hline Magma type & $\mathrm{T}\left({ }^{\circ} \mathrm{C}\right)$ & $\mathrm{P}(\mathrm{kb})$ & $\mathrm{H}_{2} \mathrm{O}($ wt. \%) \\
\hline Rhyolite & $847-863$ & $<2$ & $4-5$ \\
Trachyte & $813-845$ & & $\mathrm{ca} .4$ \\
Sodic trachyandesite & $878-950$ & & $<4$ \\
(Trachy-)andesite & $840-857$ & & $\mathrm{ca} .2$ \\
Basalt & ca. 1160 & ca. 4 & 2 \\
\hline
\end{tabular}

Methods of determination (for details see Freundt and Schmincke submitted to J. Petrol): (a) Temperatures are determined from ilmenite-magnetite paris fulfilling (or close to) $\mathrm{Mg} / \mathrm{Mn}$ equilibrium and showing no exsolution. Temperatures are bracketed by other thermometers employing amphiboles and pyroxenes

(b) Pressure estimate for rhyolite is from Al-in-amphibole barometer supported by comparison with various experimental phase diagrams. The phenocrysts of P1 rhyolite (anor-amph-mt-ilm-ap-zi) differ from the calibrated phase assemblage (bi-qz-san-pl-sphene$\mathrm{mt} / \mathrm{ilm}$ ) but the predicted zero-pressure Al-content lies exactly between that of matrix and phenocryst amphiboles. Pressure for basalt is derived from amphibole in mafic cumulates and from comparison with phase diagrams and plagioclase-melt derived $\mathrm{P}_{\mathrm{H}_{2} \mathrm{O}}$. Relative pressures are qualitatively supported by $\mathrm{Al} / \mathrm{Ti}$-ratios in clinopyroxenes

(c) Water contents are estimated from feldspar-melt equilibria and experimental phase diagrams

and barometry data, which are crucial for the magma density and viscosity estimates, are extensively evaluated elsewhere (Freundt and Schmincke submitted). Table 2 summarizes pre-eruption temperatures, pressure of crystallization, and water content of the end-member magmas of P1. The crystallization pressure of $<2 \mathrm{~kb}$ for rhyolite suggests that the $\mathrm{P} 1$ magma chamber was above $7 \mathrm{~km}$ depth in the upper crust of Gran Canaria. There are several lines of evidence which convincingly show that all component magmas erupted from a common reservoir:

(a) P1 forms a single cooling unit with no significant hiatus in the depositional sequence.

(b) All magmas are present as viscously deformed inclusions.

(c) The consistent vertical stratigraphy and compositional evolution of P1 tuff and the radial distribution of the ignimbrite sheet around Tejeda caldera are not compatible with eruption from several vents.

(d) Rhyolite and trachyte magmas had mixed in the chamber during crystallization prior to eruption.

(e) The intensity of mixing could only have been achieved in a chamber or conduit.

Temperatures of the evolved to intermediate magmas (Table 2) indicate a continuous thermal gradient in the $\mathrm{P} 1$ reservoir, whereas the approx. $300^{\circ} \mathrm{C}$ temperature gap between evolved magmas and almost aphyric basaltic magma suggests that the latter intruded the P1 chamber from a reservoir at the base of the crust only shortly prior to eruption.

\section{Density and viscosity of magmas}

Calculated magma densities and viscosities in Fig. 11 are based on the temperature and $\mathrm{H}_{2} \mathrm{O}$ data in Table 2

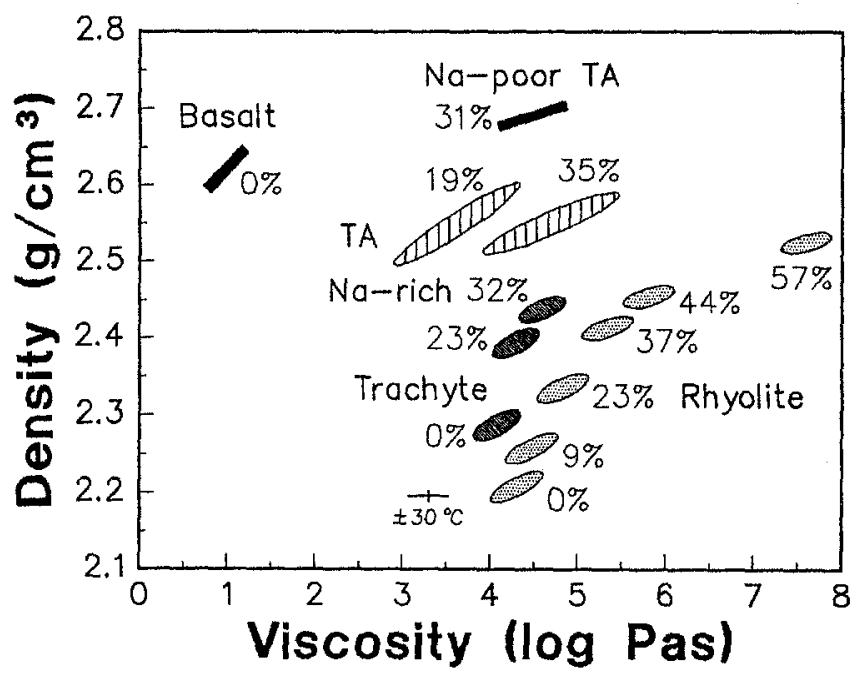

Fig. 11. Density versus viscosity diagram for $P 1$ component magmas, calculated after Bottinga et al. (1983) and Shaw (1972) for $P=2 \mathrm{~kb}$, with correction for solids following Marsh (1981). Numbers give \% crystals. Rhyolite: $\mathrm{T}=850^{\circ} \mathrm{C}, \mathrm{H}_{2} \mathrm{O}=4-5$ wt. $\%$ (length of dotted ellipses reflects $\mathrm{H}_{2} \mathrm{O}$-range). Data based on measured glass and selected modal compositions covering the observed range of crystal contents from 9 to $57 \%$. Melt data $(0 \%)$ for comparison. Trachyte: $\mathrm{T}=825^{\circ} \mathrm{C}, \mathrm{H}_{2} \mathrm{O}=4-5 \mathrm{wt} . \%$ (densely hatched ellipses). Data based on matrix composition, recalculated from bulk rock and mineral compositions, and observed modal compositions with 23 to $32 \%$ crystals. Melt $(0 \%)$ data for comparison. The error cross shows the variation in density and viscosity around any rhyolite or trachyte data point when temperature is varied by $\pm 30^{\circ} \mathrm{C}$. Na-rich $\mathrm{TA}$ : sodic trachyandesite, $\mathrm{T}=880-950^{\circ} \mathrm{C}$, $\mathrm{H}_{2} \mathrm{O}=2-4$ wt. \% (both ranges reflected by length of hatched ellipses). Based on recalculated matrix of two rocks, $19 \%$ crystals and $\mathrm{SiO}_{2}=58.4$ wt. $\%, 35 \%$ crystals and $\mathrm{SiO}_{2}=62.5 \mathrm{wt} . \%$. Na-poor $T A$ : sodium-poor trachyandesite, $\mathrm{T}=840-940^{\circ} \mathrm{C}$ (black bar), $\mathrm{H}_{2} \mathrm{O}=2$ wt. $\%, 31 \%$ crystals, recalculated matrix. Basalt: $\mathrm{T}=1100$ $1200{ }^{\circ} \mathrm{C}$ (black bar), $\mathrm{H}_{2} \mathrm{O}=2$ wt. $\%$, bulk rock assumed as melt composition $(0 \%)$. The considered ranges in $\mathrm{H}_{2} \mathrm{O}$ content and temperature show that uncertainties in their determination are unlikely to qualitatively change the density and viscosity relationships among the magmas

but we have also considered wide ranges around these values. Magma densities and viscosities were determined from melt data by correction for phenocrysts employing the Roscoe formula $\eta_{x}=\eta_{o}^{*}\left(1-1.67^{*} X\right)^{-2.5}$ suggested by Marsh (1981), where $X$ is the fraction of crystals, and $\eta_{x}$ tends to infinity at $>60 \%$ crystal content.

The wide range in crystal content from 9 to $57 \%$ causes wide ranges in rhyolite magma density and viscosity. Both increase with crystallinity (Fig. 11) and indicate that the rhyolite magma was stably zoned from crystalpoor at the top to highly phyric at the bottom, in agreement with the observed order of eruption. The viscosities of crystal-poor rhyolite and evolved trachyte are approximately equal, but the viscosity of highly phyric rhyolite is up to almost three orders of magnitude higher. The density of evolved trachyte magma is intermediate between the lower density of crystal-poor rhyolite and the higher density of highly phyric rhyolite magma (Fig. 11), which prohibits a stable vertical zonation with one magma on top of the other. This density relationship is dominantly controlled by the crystal contents of the magmas 
and holds even when quite large uncertainties in temperatures and water contents are considered.

Density increases from evolved through mafic trachyte to sodic trachyandesite whereas viscosity decreases (Fig. 11), suggesting that evolved trachyte rested atop sodic trachyandesite. The density of sodium-poor trachyandesite is higher than that of sodium-rich trachyandesite because of higher iron-content in the melt and more pyroxene in the mode. Sodium-poor trachyandesite magma even exceeds the hot basaltic melt in density (Fig. 11). Basalt magma intruding the bottom of the chamber might thus have penetrated, and mixed with, the sodium-poor trachyandesite magma layer, but we did not find evidence for this process, as might be expected if the volume fraction of this magma were as small in the chamber as it is in the P1 deposit.

\section{Geometrical structure of the zoned reservoir}

Constraints on the zonation geometry include the component magma volumes and the Tejeda caldera diameter. The end-member magma volumes are $10 \mathrm{~km}^{3}$ rhyolite (including $\mathrm{R} 1=0.5 \mathrm{~km}^{3}$ ), $6 \mathrm{~km}^{3}$ trachyte-trachyandesite, $26 \mathrm{~km}^{3}$ basalt and $<1 \mathrm{~km}^{3}$ sodium-poor trachyandesite. The total volume of evolved to intermediate magmas of ca. $16 \mathrm{~km}^{3}$ gives a minimum volume for the P1 magma chamber; the basalt magma only intruded during or just before eruption. The chamber volume was probably larger because very dense and viscous crystalrich rhyolite magma was hard to extract and a substantial fraction may have been trapped in the reservoir.

The diameter of the steeply (about $60^{\circ}$ ) inward dipping Tejeda caldera scarp (Schmincke and Swanson 1966; Schmincke 1967; 1968) is approx. $15 \mathrm{~km}$. The diameter of an upper-crustal magma chamber is assumed to equal the about $10-\mathrm{km}$ diameter probably defined by the actual faults at some depth (assuming a ring-fault caldera; Smith 1979). In a flat cylindrical chamber, the aspect ratios (depth/width) of trachyte-trachyandesite and rhyolite magma layers would be $<0.01$. Even under a hemispheric cupola, where the central depth of the upper layer would be increased relative to lower layers, aspect ratios remain $<0.07$.

Several arguments show that the zonation of the P1 reservoir was not a simple vertical stack of magma layers. Freundt and Schmincke (submitted) demonstrate that the trachyte-trachyandesite magma group, especially the sodic trachyandesite, was strongly contaminated by wall-rock derived melts or fluids, suggesting that these magmas remained in contact with the chamber walls. Also, the pre-eruption temperature of trachyte varies between different samples in the range 813 to $845^{\circ} \mathrm{C}$ and is lower than the 847 to $863^{\circ} \mathrm{C}$ of rhyolite, which is constant for different samples and has a small deviation around the mean of $850^{\circ} \mathrm{C}$ [highly phyric rhyolite was not cooler than crystal-poor rhyolite because it contains accumulated crystals (about $20 \%$ ) and resided deeper in the chamber]. It is not likely that cooler trachyte lay below hotter rhyolite. Density data (Fig. 11) suggest that trachyte was in gravitational equilibrium with rhyolite of intermediate crystal content, but that crystal-poor rhyolite was less dense and very crystal-rich rhyolite was denser.

While compositional zonation in magma chambers is commonly envisaged as a vertical change in composition corresponding to a vertically stable density stratification (e.g., Wörner and Schmincke 1984; Fridrich and Mahood 1987; Boden 1989), we propose that major boundaries between compositional domains in the P1 reservoir were both vertical and horizontal. Our model of the magma chamber zonation at the time of eruption envisages a core of highly phyric rhyolite, capped by a thin layer of crystal-poor rhyolite, and mantled by an envelope of trachyte-trachyandesite magma. Aspect ratios of a cylindrical trachyte ring and rhyolite core would both be $>0.1$ in this model.

Density data for low crystal contents (Fig. 11) suggest that during an early stage of crystallization trachyte magma had underlain rhyolite magma. But the rate and amount of precipitation and accumulation of crystals were higher in rhyolite than in trachyte magma; high crystallization rates of $>50 \%$ over 10 to $20^{\circ} \mathrm{C}$ cooling are not unusual for hydrous rhyolite (Whitney 1988). This required a reorganization of chamber zonation where trachyte had to migrate to a position lateral to rhyolite of equal density, so that the level of equal density changed with time. Since crystallization was still continuing, the zonation at the time of eruption must be considered as a transient state.

\section{Thermomechanical constraints}

In the following section we attempt to check if our interpretation of mixing structures is compatible with modeled physical states of the magmas during mixing. Temperature-, viscosity- and density-contrast, as well as the vigor and duration of convection, control the efficiency of magma mixing, i.e., the scale of heterogeneities. Hybridization can only be achieved where mechanical mixing has reduced the width of heterogeneities to a scale over which slow chemical diffusion can homogenize compositional gradients during the time interval between mixing and quenching. Thermal equilibration between mixed magmas is orders of magnitude faster than chemical equilibration so that the newly established equilibrium temperature controls the physical behavior of the component magmas during small-scale mixing (Sparks and Marshall 1986). For a typical thermal diffusion coefficient of $5^{*} 10^{-3} \mathrm{~cm}^{2} / \mathrm{s}$ thermal equilibration over 10 to $100 \mathrm{~m}$ takes 150 to 15000 years, a small fraction of the probable $10^{5}$ years lifespan of a large magma chamber. Heterogeneities up to $10-\mathrm{cm}$ wide can be thermally equilibrated even during $1-\mathrm{m} / \mathrm{s}$ ascent through a 5 -km-long eruptive conduit.

The mechanical behavior of the magmas after thermal equilibration is determined by the relative position $T_{X}=\left(T_{M}-T_{S}\right) /\left(T_{L}-T_{S}\right)$ of the mixing temperature $\left(T_{M}\right)$ between the liquidus $\left(T_{L}\right)$ and solidus $\left(T_{S}\right)$ temperatures of each magma. $T_{X}$ determines the crystallinity and, hence, the viscosity of the magmas. We have performed 
model calculations employing the program MAGMIX by Frost and Lindsay (1988), which calculates the mixing temperature as a function of component magma proportions, initial temperatures, and heats of crystallization and melting of minerals. Magma crystallinity at each temperature is calculated from the analytical function given by Marsh (1981), in which a best-fit constant $\sigma$ determines whether crystallinity changes more or less uniformly over the temperature interval (e.g., $\sigma=2$ ) or changes steeply around the mid-point $\left(T_{X}=0.5\right)$ between solidus and liquidus (e.g., $\sigma=0.2$ ). Magma viscosity is calculated from mixing temperature and crystallinity; we have modified the program to employ the Roscoe formula as given here. Some restrictions for the application of MAGMIX calculations to P1 magmas must be noted. The crystallization behavior of the hydrous silicic melts differs from basalts in that massive crystallization occurs closer to the solidus rather than at $T_{X}=0.5$. Also, quench crystallization may occur in magma cooled close to, or beneath, its solidus during mixing. The crystal content is further affected by gravitational accumulation or fractionation of crystals, as can be shown for crystalrich and crystal-poor rhyolite, respectively (Freundt and Schmincke submitted).

The mixed-magma associations of $\mathrm{P} 1$ can be considered in terms of two major mixing pairs, (a) rhyolite/ trachyte and (b) rhyolite/basalt. These pairs exhibit significantly contrasting temperature differences and viscosity ratios: (a) ca. $25^{\circ} \mathrm{C}, 1$ to $10^{3}$; (b) ca. $300^{\circ} \mathrm{C}$, $10^{3}$ to $10^{7}$. It should be kept in mind, however, that contributions from other component magmas were always present and that the component magmas were themselves compositionally zoned.

Rhyolite-basalt mixtures. Rhyolite-basalt MAGMIX models with basalt initially at $1160^{\circ} \mathrm{C}$ and at its liquidus temperature consider a very wide range of $\mathrm{H}_{2} \mathrm{O}=0$ to 4 wt.\%. Basalt would become solid (i.e., crystallinity exceeds $60 \%$; see Marsh 1981) at basalt fractions $X_{B}=$ 0.27 to 0.4 in a mixture with rhyolite magma initially $850^{\circ} \mathrm{C}$ (Fig. 12a). At $X_{B}<0.3$ as in units R1 to R3, the basaltic magma would be quenched and further viscous mixing inhibited, even though the mixing temperature would exceed the rhyolite liquidus for $X_{B}>0.14$ (Fig. 12b). Easy mixing should be facilitated by low and similar viscosities for both mixing members at $X_{B}>0.4$ (Fig. 12a), reflecting conditions for units $\mathrm{M} 1$ through B3. Though temperature was high (about $1000^{\circ} \mathrm{C}$ ), the M1 mixture $\left(X_{B}=0.4\right.$ to 0.5 and viscosity approx. $10^{3}$ Pas) remained inhomogeneous (Fig. 5E), whereas during the $\mathrm{B} 2$ phase $\left(X_{B}>0.9\right.$, viscosity approx. 10 Pas) nearly complete hybridization was achieved. Since a significant decrease in ascent velocity (i.e., enhanced duration of mixing) is unlikely, the different mixing maturity can be attributed mainly to the viscosity difference and to superheating of rhyolite in the basalt, causing vigorous degassing (Fig. 6B) which facilitated rapid destruction of the rhyolite.

Conditions for unit $\mathrm{R} 4\left(X_{B}=0.2\right.$ to 0.5$)$ assume a transitional position in Fig. 12. The mixing temperature

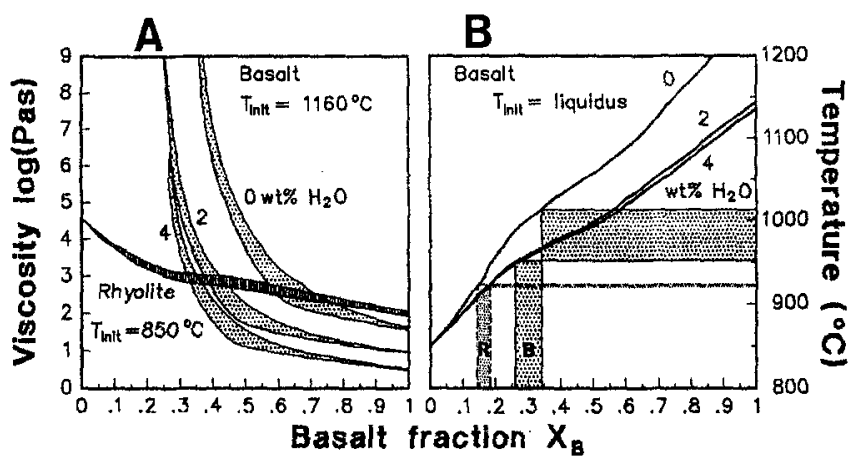

Fig. 12A, B. Thermomechanical conditions of rhyolite-basalt magma mixing. A Magma viscosity versus basalt fraction in the mixture. Basalt magma $(\sigma=0.2-1)$ initially at $1160^{\circ} \mathrm{C}$, which is close to liquidus for hydrous magma but ca. $100^{\circ} \mathrm{C}$ below liquidus for dry magma, becomes solid at basalt fractions of about 0.27 to 0.4 . Rhyolite is initially at $850^{\circ} \mathrm{C}$ and $5 \mathrm{wt} . \% \mathrm{H}_{2} \mathrm{O}(\sigma=2$; influence of rhyolite $\sigma$ on basalt curves is not significant). B Mixing temperature versus basalt fraction. Basalt magma is initially at liquidus temperature of both dry and hydrous compositions. Non-linearity of mixing temperatures shows the heat effect of crystallization/ dissolution. Solid lines $B$ show the range of temperature (950 to $1010^{\circ} \mathrm{C}$ ) and basalt fraction $(0.26$ to 0.34$)$ below which basalt magma becomes solid. These temperatures are higher than the liquidus temperature of hydrous rhyolite (ca. $920^{\circ} \mathrm{C}$; dashed line), which, therefore, gets superheated at any basalt fractions exceeding 0.14 to $0.18(R)$

would stay well above $950^{\circ} \mathrm{C}$ for $X_{B}>0.3$, i.e., basalt would remain viscous with crystal fractions $<60 \%$. In this range, a variety of viscously deformed to angular basalt inclusions could have formed during mixing and fragmentation upon eruption. At $X_{B}<0.3$, basalt inclusions would be cooled below $950^{\circ} \mathrm{C}$ and solidify. A conductive cooling model (Eq. 6 for spherical bodies, p. 257 in Carslaw and Jaeger 1959) shows that inclusions smaller than $1 \mathrm{~cm}$ in diameter (e.g., Fig. 5D, E) should become solid within a few seconds after contact with the rhyolite. Basalt inclusions 10 to $100 \mathrm{~cm}$ in diameter would form a solid crust after $5 \mathrm{~min}$ to $8 \mathrm{~h}$, but their cores would remain viscous for $20 \mathrm{~min}$ to $40 \mathrm{~h}$, which represent time intervals comparable to those of evacuation, eruption, transport, and deposition. Thus, small viscously deformed basalt inclusions cannot have originated at the initial basalt-rhyolite contact but formed during disruption of large viscous basalt bodies upon eruption and surface transport. Since large bodies can sustain a solid crust surrounding a viscous core for substantial time intervals, their disruption can contribute both angular and viscous fragment types.

Rhyolite-trachyte mixtures. A MAGMIX model mixing rhyolitic or trachytic with trachyandesitic magma (3 wt. $\% \mathrm{H}_{2} \mathrm{O}$ ) in the temperature range 850 to $900{ }^{\circ} \mathrm{C}$ yields a qualitatively similar pattern to Fig. $12 \mathrm{a}$, showing that intense mixing would only be likely at trachyandesite fractions $>0.5$ whereas at fractions $<0.3$ trachyandesite magma would become highly viscous to solid. This explains the preservation of trachyandesite inclusions in the intense trachyte-rhyolite mixture of Fig. 7B. It also 
implies that despite the higher temperature the trachyandesite-rhyolite boundary in the magma chamber would have been more stable than the trachyte-rhyolite boundary. The high viscosity at the contact with rhyolite, the high density, and the deeper position of trachyandesite in the chamber can explain why this magma was much less involved in mixing with rhyolite than was the evolved trachyte.

MAGMIX calculations for rhyolite-trachyte mixtures yield crystallinities that differ from observed modal compositions and show great variability with changing values of $\sigma$, which is unknown. Resulting viscosities are, therefore, unreliable. Since rhyolite and trachyte magma temperatures are well above the respective solidi and their difference is small, the heat effect of crystallization during mixing can be ignored and no quenching occurs. Therefore, we only consider density and viscosity relations between these magmas based on their phenocryst content.

Subtracting feldspar from the mode yields crystallinities $<10 \%$ of rhyolite and trachyte magma at the beginning of feldspar crystallization. Under these conditions, the viscosity of both magmas would be very similar (I in Fig. 13) and the melt density difference approx.

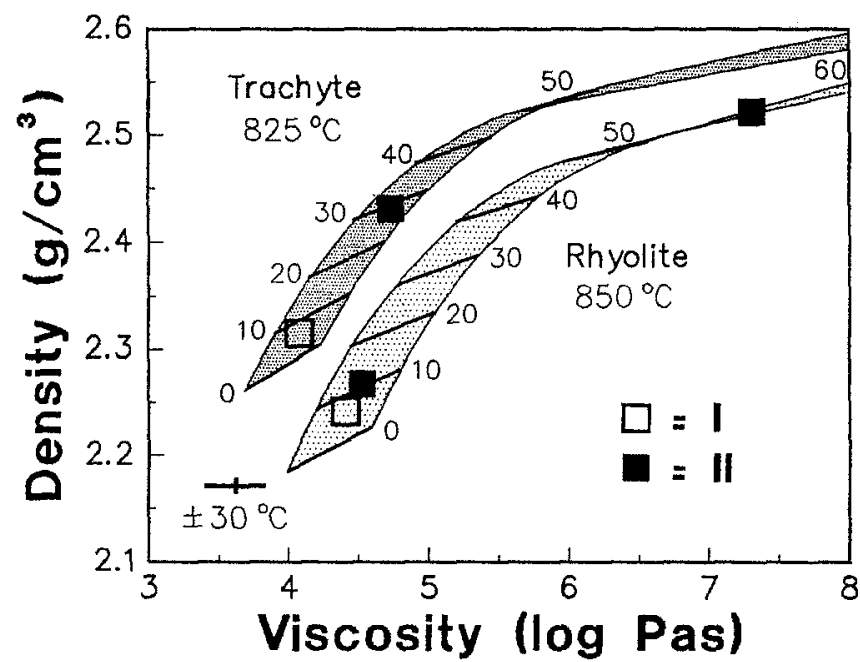

Fig. 13. Density-viscosity diagram illustrating mixing conditions for trachyte (densely dotted, $\mathrm{T}=825^{\circ} \mathrm{C}$ ) and rhyolite (lightly dotted, $\mathrm{T}=850^{\circ} \mathrm{C}$ ). Calculations as in Fig. 11 for crystal contents of 0 to $60 \%$. Bold lines connect data points for 4 and 5 wt. $\% \mathrm{H}_{2} \mathrm{O}$ for each crystal content and composition. The error cross gives the variation in response to $\pm 30^{\circ} \mathrm{C}$ temperature change, covering uncertainties in temperature determinations as well as the range of mixing temperature to which the magmas may equilibrate. Open squares $I$ indicate conditions of mixing at the beginning of feldspar crystallization when crystal content of the magmas was $<10 \%$. Trachyte magma was denser than rhyolite magma but both had a similar viscosity. Black squares $I I$ indicate conditions at the time of eruption when rhyolite was zoned from 9 to $57 \%$ crystal content and trachyte contained 23 to $32 \%$ crystals. Density and viscosity relations were variable in this case, depending on which part of the zoned rhyolite magma became mixed with trachyte. If $\mathrm{H}_{2} \mathrm{O}$ concentrations had been higher at the time of eruption, reductions by $0.04 \mathrm{~g} / \mathrm{cm}^{3}$ and $0.6 \log$ Pas per +1 wt. $\% \mathrm{H}_{2} \mathrm{O}$ would not qualitatively change density and viscosity relations unless much higher $\mathrm{H}_{2} \mathrm{O}$ content in rhyolite than in trachyte were assumed, which is unlikely as saturation probably occurs at about 6 wt. $\% \mathrm{H}_{2} \mathrm{O}$
$0.07 \mathrm{~g} / \mathrm{cm}^{3}$, facilitating intense mixing and hybridization. Temperatures at this stage may have been somewhat higher than indicated in Fig. 13, but this would not qualitatively change the relationship between the magmas (as shown by the $\pm 30^{\circ} \mathrm{C}$ error bar) unless the temperature difference between them had been much greater, for which there is no evidence.

Viscosity and density relations were variable at the time of eruption; trachyte with crystal fractions of 23 to $32 \%$ would have a similar viscosity and higher density than rhyolite with small to intermediate crystal content but would be less dense and much less viscous than highly phyric rhyolite magma (II in Fig. 13). The viscosity contrast between trachyte and rhyolite with less than about $30 \%$ crystals would, however, be small enough to facilitate the formation of intensely banded and mottled rhyolite-trachyte mixtures (Fig. 7 A, B) during eruption.

\section{Mixing processes}

We have shown that the presence of strongly resorbed anorthoclase crystals in the basalt is compatible with mixing of basaltic and rhyolitic magmas during the course of eruption. Possible mixing sites are the bottom of the P1 magma chamber, where basaltic melt intruded shortly before or during eruption, and the conduit through which magmas were discharged simultaneously.

According to Campbell and Turner (1986), low-viscosity basaltic magma entering the base of a reservoir would not mix with the resident silicic magma as long as $w^{*} d / v<7$ and viscosity ratio $>400$. Mixing would only occur at $w^{*} d / v>70$, where $w=$ basalt ascent velocity, $d=$ diameter of feeding conduit, and $v=$ kinematic viscosity of resident magma. Estimated rhyolite-basalt viscosity ratios clearly exceed 400 (Fig. 11) and an average $v=4500 \mathrm{~m}^{2} / \mathrm{s}$ of rhyolite magma would only require that $w^{*} d<31500$ to prevent mixing, a condition fulfilled for any reasonable mode of basalt intrusion (compare Wilson and Head 1981). Isothermal fluid dynamics would thus suggest that no mixing occurred during injection of the basaltic magma into the rhyolite reservoir. Thermomechanical considerations do, however, show that superheating of rhyolite magma in contact with basalt would reduce the viscosity ratio down to 10 to 100 (Fig. 12a), so that limited mixing might occur at $w^{*} d>$ 315 (which still is an unlikely condition). Light superheated plumes of rhyolite melt may have carried few basaltic inclusions to the top of the chamber to become erupted with R1.

Eichelberger (1980) and Huppert et al. (1982) suggested destruction of magma chamber stratification by convective overturn due to density reduction in the lower mafic magma by degassing upon cooling against overlying silicic magma, thereby possibly triggering the eruption. The resulting chaotic mixing pattern would be controlled by local floating of basalt foam blobs and intensity of mixing would depend on duration of this process. The "pillow-like" basalt inclusions especially of unit R4 (Fig. 5D) show that foaming of basalt during mixing and thermal equilibration with rhyolite did indeed occur. 
However, the most vesicular basalt inclusions would be expected to have reached the highest level in the magma chamber whereas we find rather dense basalt inclusions in first-erupted R1 and most-vesicular inclusions in R4. The low vesicularity of basalt inclusions in R1 cannot result from welding compaction because the basalt would have almost instantaneously solidified upon contact with the rhyolite. We think that vesiculation of the hydrous basalt can be attributed to $\mathrm{CO}_{2}$ release at chamber level and $\mathrm{H}_{2} \mathrm{O}$ release during contact with rhyolite and depressurization during ascent, but convective overturn in the chamber was probably not the major mixing mechanism between basalt and rhyolite.

Because of the very systematic temporal evolution of mixed magma proportions, despite the variety of components in $\mathrm{P} 1$, we favor a more systematic process of magma mixing such as the deformation of interfaces during withdrawal from the reservoir as studied by Blake (1981), Koyaguchi (1985) and Blake and Ivey (1986). When the depth of overlying magma falls below a critical value determined by outflow rate and density and viscosity contrast, the magma interface deforms into an inverted funnel and magmas enter the conduit simultaneously. During ascent through the conduit, the boundary between the magmas becomes unstable and mixing proceeds with an intensity controlled by discharge rate, viscosity contrast and length of the conduit (Freundt and Tait 1986). Published models and experiments on these processes generally refer to central-vent eruptions; our assumption of a ring-fracture conduit for the P1 eruption does not, however, affect the general withdrawal and mixing mechanisms.

The proportions in which the component magmas are withdrawn from the chamber are determined by the outflow rate, density- and viscosity-contrast, and the depth of the layers and their geometrical configuration. Since upper-layer depth gradually falls during eruption, there is a systematic change to increasing proportions of the lower-layer magma. This is well seen in the subsequent gradual increases of trachyte and basalt fractions relative to rhyolite (Fig. 8 b). We have, however, noted differences in the pattern of changing rhyolite-trachyte proportions sectorially around the caldera; the maximum proportion of trachyte varies and is reached at slightly different levels, locally the eruption began or ended with a trachyte-rich composition. These sectorial changes can be better reconciled with our model of a concentrically zoned, rather than a layered, magma chamber tapped by a ring-fissure conduit, where the conduit entrance would in some sectors lie initially well within the rhyolite volume and in other sectors close to the steep rhyolite-trachyte boundary. Minor recurrences in component proportions (Fig. 8c) reflect fluctuations in magma outflow rate; a temporal decrease in this rate would cause a decrease in the fraction of lowerlayer magma. Since these recurrences also vary sectorially, they imply variable discharge rates at a given time during eruption, which can only be reconciled with a ring-fissure rather than a central conduit.

Mixing between trachyte and rhyolite magmas during their crystallization is probably closely related to reor- ganization of the chamber from a layered to a concentric geometry in response to changing density relations. Density and viscosity contrasts remained small and allowed for convective mixing driven by overall cooling as well as crystallization-induced density changes. Mixing would affect both magmas most strongly in a region next to their interface, because (a) the interface is the major site of mixing as it becomes unstable during relative motion of the magmas, and (b) lateral exchange of material is limited in a low aspect ratio (depth/width) magma body where convection cells form horizontal arrays (e.g., Oldenburg et al. 1989). The depth of this "mixing region" is unknown but was probably similar in both magma bodies when their physical properties were similar. We have noted that almost all trachyte samples show signs of rhyolite admixing whereas many rhyolite samples do not show evidence for admixing of trachyte. In our concentric model the width of the trachyte mantle would be only a quarter of the radius of the rhyolite core, and if the "mixing region" had been as wide as the trachyte envelope, the entire volume of trachyte would be affected by mixing whereas a central zone of the rhyolite core could remain unaffected. Mixing between trachyte and crystal-rich rhyolite magma also became retarded by a drastic increase in rhyolite viscosity when crystal content exceeded $30 \%$ during late stages of rhyolite crystallization.

In addition to convective mixing, it is also possible that crystals sank from rhyolite into trachyte magma during early stages when trachyte magma was denser, temperatures relatively high (about $880^{\circ} \mathrm{C}$ ) and viscosities low, and the low crystal content allowed for unhindered settling. Stoke's settling velocities of feldspar (1 to $3 \mathrm{~mm}$ ) and amphibole $(0.5$ to $1 \mathrm{~mm})$ crystals are 8 to $80 \mathrm{~m} / \mathrm{a}$ and 5 to $20 \mathrm{~m} / \mathrm{a}$, respectively; in trachyte magma, these rates are $40 \%$ lower. Crystals would thus need only 1 to 20 years to sink through $100 \mathrm{~m}$. However, the effective rate of settling is controlled by the ratio of sinking velocity to convection velocity (Marsh 1988), which might have been low under these magmatic conditions.

\section{Conclusions}

\section{Magma chamber zonation}

Chemically zoned volcanic deposits commonly represent evacuated portions of a magma chamber in which crystallinity increased downwards towards lower silica content as a result of fractional crystallization (e.g., Wörner and Schmincke 1984), or in which crystal-poor magma had an upward increasing volatile concentration (e.g., Wolff et al. 1990), conditions which favor a stable layered zonation in the chamber and its preservation in the deposit. The difference with the P1 magmas is that, despite their long residence in a common reservoir, rhyolite is not a derivate of trachyte, but both evolved independently and are only related by partial syn-crystallization mixing (Freundt and Schmincke submitted). Crystallization of both magmas was not related and 


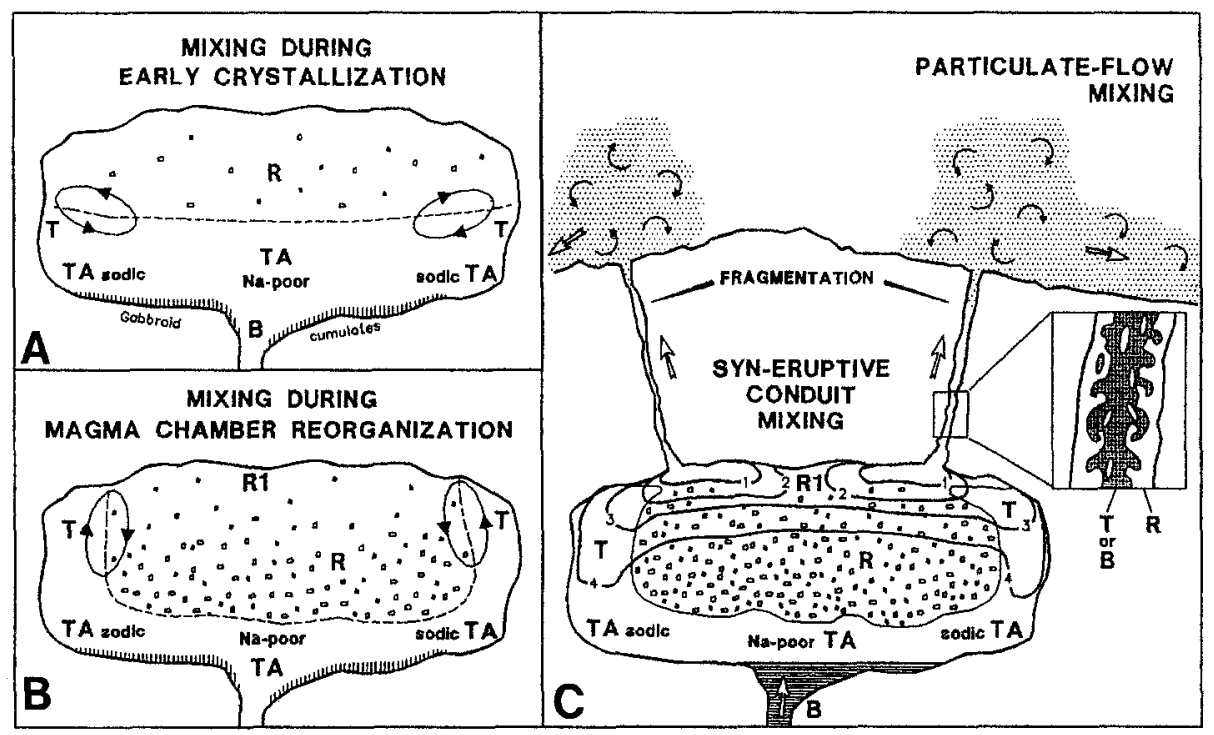

Fig. 14A, B. Sketch of magma mixing during crystallization and evacuation of the P1 magma chamber. A Convective mixing at the interface between vertically zoned rhyolite and trachyte magmas during early stage of crystallization. B Mixing during reorganization to a zonation that is both vertical and lateral (concentric). Increased viscosity of highly phyric rhyolite reduces mixing during late-stage crystallization. C Evacuation through ring fissures while basalt magma $(B)$ intrudes at the base. Evacuation isochrons (1-4) outline magma simultaneously withdrawn at four points in time to become mixed during ascent in the conduit (inset). Further mixing commences during surface transport after magma fragmentation. $R$ : rhyolite; $T$ : trachyte, $T A$ : trachyandesite; $B$ : basalt evolved largely independently. Steep crystallinity-temperature functions of hydrous silicic magmas can potentially create large differences in crystallinity between magmas within a similar and narrow temperature interval. Calculated densities of the component magmas suggest that trachyte resided below rhyolite in the P1 magma chamber (Fig. 14a) during early stages of low crystallinity. However, rates of precipitation and accumulation became higher in the rhyolite than in the trachyte magma so that rhyolite became more crystal-rich than the less silicic trachyte and developed a gradient of downward increasing crystallinity and density. This changed the density relations between the magmas and required a transition from the layered structure to a zonation with trachyte lateral to rhyolite of equal density. Syncrystallization mixing of rhyolite and trachyte magmas was probably related to this reorganization of chamber zonation (Fig. 14a, b). Supported by temperature relations, magma withdrawal considerations, and chemical arguments involving exchange between trachyte magma and wall-rock (Freundt and Schmincke submitted; Freundt 1989), we propose a concentric geometry of zonation at the time of eruption, with a central rhyolite core mantled by a marginal sheath of trachyte zoned downwards to sodic trachyandesite (Fig. 14b). Denser Na-poor trachyandesite resided at the bottom of the chamber. We wish to stress, however, that this zonation was a transient state since ongoing crystallization at different rates just happened to be interrupted by eruption.

\section{Magma mixing}

Compositional zonation of the magma chamber is commonly preserved with little mixing in high-volume ignim- brites erupted from batholith-size reservoirs (e.g., Smith 1979) or in low-volume tephra erupted from small chambers (e.g., Wörner and Schmincke 1984), where in both cases top zones are evacuated according to their vertical density gradient. The intermediate-volume composite flow $\mathrm{P} 1$, however, is a complex example of intense dynamic mixing of four compositionally zoned magmas from early stages of crystallization to final ignimbrite deposition, where a large spectrum of textures reflects the variable mixing conditions. Intense magma mixing during the formation of $\mathrm{P} 1$ can be attributed to the complex reservoir zonation gecmetry associated with the vertical density gradient, to a high withdrawal depth determined by the high viscosity contrast between basaltic and silicic magmas, and to the probably high discharge rate, possibly enhanced by intrusion of the large volume of basaltic melt.

We have here attempted to identify the mixing processes involved by textural and chemical analyses and to characterize the physical conditions under which these processes operated. It is obvious that mutual mineral inclusions reflect mixing of magmas during crystallization, when sufficient time was available for chemical diffusion to homogenize blended magmas. Rocks with banded and mottled textures of mixed but sharply separated compositional domains are throught to result from magma mixing during eruption, when there was not time for chemical diffusion to take effect. However, this criterion seems to hold only for mixtures involving highviscosity magmas such as rhyolite-trachyte associations or rhyolite-rich mixtures of rhyolite and basalt. For basalt-dominated rocks containing less than $20 \%$ rhyolite we have shown that the superheated rhyolite magma was rapidly destroyed and dissolved, and remaining anorthoclase crystals were strongly resorbed under the con- 
trol of emplacement temperature and cooling conditions in the deposit. This implies efficient chemical diffusion even though mixing occurred only during eruption. Syneruptive magma mixing thus can achieve almost complete homogeneization provided that temperature is high and viscosity low.

The eruption of $\mathrm{P} 1$ proceeded through a ring fissure and was probably triggered by both water saturation of the rhyolite magma and intrusion of the hot basaltic melt into the chamber (see Freundt and Schmincke submitted), which caused only limited mixing. The proportions of the component magmas changed systematically during syneruptive mixing. Downward propagation of the withdrawal zone from crystal-poor volatile-rich rhyolite magma under the cupola of the chamber into increasingly viscous crystal-rich rhyolite forced evacuation to proceed sideways towards lower viscosity trachyte magma (Fig. 14c). The initial separation of trachyte from the conduit entrance varied along the ring fissure resulting in variable onset of trachyte withdrawal around the caldera. The fraction of trachyte-trachyandesite magma in the erupted mixture increased until its extractable volume was exhausted abruptly. For a brief period, the eruption returned to be dominated by highly phyric rhyolite magma but since its thickness had already dropped below a critical value, low-viscosity basaltic magma became withdrawn simultaneously. The basalt fraction increased and rapidly dominated the erupted composition. The rhyolite fraction dropped to insignificant amounts and only increased slightly at the end of the eruption under waning basalt discharge rate and strong conduit erosion.

Syn-eruptive mixing of the magmas dominantly occurred during ascent in the conduit (Fig. 14c). Rhyolite and trachyte magmas of similar temperature and viscosity, except for extremely crystal-rich rhyolite, mixed easily forming intensely banded domains. Slightly hotter trachyandesite magma contributed in smaller fractions and became quenched, forming coherent, more homogeneous magma blebs. Basaltic magma was instantly quenched upon mixing with large fractions of rhyolite magma about $300^{\circ} \mathrm{C}$ cooler. At basalt fractions larger than $15 \%$, rhyolite magma became superheated and mixing intensified. Textural and compositional comparisons of mixed tuff and inclusions show that heterogeneities in the conduit partly maintained a size larger than the inclusions themselves, which are, therefore, not representative of the mixed composition. Fragmentation of the hydrous magmas at shallow level (Fig. 14c) strongly reduced the size of heterogeneities at least to a mm-scale, so that tuff samples represent the bulk composition of the magma mixture during each eruptive pulse.

Acknowledgements. This work is part of AF's Ph.D. thesis at the Ruhr-Universität Bochum. A stipend by the Studienstiftung des deutschen Volkes to AF and a grant by the Deutsche Forschungsgemeinschaft to HUS (Grant Schm 250/36-1) are gratefully acknowledged. An earlier version of this paper benefitted greatly from comments by Steve Sparks, Wes Hildreth and Bruce Marsh.

\section{References}

Anderson AT (1976) Magma mixing: petrological process and volcanological tool. J Volcanol Geotherm Res 1:3-33

Bacon CR, Metz J (1984) Magmatic inclusions in rhyolites, contaminated basalts, and compositional zonation beneath the Coso volcanic field, California. Contrib Mineral Petrol 85:346-365

Blake S (1981) Eruptions from zoned magma chambers. J geol Soc London 138:281-287

Blake S, Ivey GN (1986) Magma-mixing and the dynamics of withdrawal from stratified reservoirs. J Volcanol Geotherm Res 27:153-178

Boden DR (1989) Evidence for step-function zoning of magma and eruptive dynamics, Toquima Caldera Complex, Nevada. $\mathrm{J}$ Volcanol Geotherm Res 37:39-57

Bottinga Y, Richet P, Weill DF (1983) Calculation of the density and thermal expansion coefficient of silicate liquids. Bull Mineral 106:129-138

Bowen NL (1928) The evolution of the igneous rocks. Princeton University Press, Princeton, NJ, USA, pp 334

Bunsen (1851) Über die Prozesse der vulkanischen Gesteinsbildungen Islands. Annal Phys Chem 83:197-272

Campbell IH, Turner JS (1986) The influence of viscosity on fountains in magma chambers. J Petrol 27:1-30

Carslaw HS, Jaeger JC (1959) Conduction of heat in solids. Oxford University Press, Oxford, UK, pp 510

Eichelberger JC (1980) Vesiculation of mafic magma during replenishment of silicic magma reservoirs. Nature 288:446-450

Freundt A (1989) Composite flow P1 on Gran Canaria: evolution of a rhyolite-trachyte-basalt magma system culminating in mixed-magma eruption and formation of silicic and basaltic welded ignimbrite. $\mathrm{PhD}$-thesis, Ruhr-Universität Bochum, FRG, pp 444

Freundt A, Schmincke HU (1993a) Emplacement and welding of a basaltic and silicic ignimbrite, composite flow P1, Gran Canaria. Bull Volcanol (in prep)

Freundt A, Schmincke HU (1993b) Magmatic evolution at the turn from basaltic to silicic shield volcanism on Miocene Gran Canaria, Canary Islands: I. Petrography, mineral chemistry, and temperature and depth of magma chambers. J Petrol (submitted)

Freundt A, Schmincke HU (1993c) Magmatic evolution at the turn from basaltic to silicic shield volcanism on Miocene Gran Canaria, Canary Islands: II. Geochemistry and petrogenesis. J Petrol (submitted)

Freundt A, Tait SR (1986) The entrainment of high-viscosity magma into low-viscosity magma in eruption conduits. Bull Volcanol 48:325-339

Fridrich CJ, Mahood GA (1987) Compositional layers in the zoned magma chamber of the Grizzly Peak Tuff. Geology 15:299-303

Frost TP, Lindsay JR (1988) MAGMIX: A BASIC program to calculate viscosities of interacting magmas of differing composition, temperature, and water content. Comput Geosc 14:213228

Hildreth W (1981) Gradients in silicic magma chambers: implications for lithospheric magmatism. J Geophys Res 86:1015310192

Hildreth W (1983) The compositionally zoned eruption of 1912 in the Valley of Ten Thousand Smokes, Katmai National Park, Alaska. J Volcanol Geotherm Res 18:1-56

Huppert HE, Sparks RSJ, Turner JS (1982) Effects of volatiles on mixing in calc-alkaline magma systems. Nature 297:554-557

Jørgensen KA (1980) The Thorsmörk ignimbrite: an unusual comenditic pyroclastic flow in southern Iceland. J Volcanol Geotherm Res $8: 7-22$

Koyaguchi T (1985) Magma mixing in a conduit. J Volcanol Geotherm Res 25:365-369

Le Maitre RW, Bateman P, Dudek A, Keller J, Lameyre J, Le Bas MJ, Sabine PA, Schmid R, Sørensen H, Streckeisen A, Woolley AR, Zanettin B (1989) A classification of igneous rocks and glossary of terms. Recommendation of the IUGS sub- 
commission on the systematics of igneous rocks. Blackwell Scientific Publ, Oxford, UK, pp 193

Lipman PW, Christiansen RL, O'Connor JT (1966) A compositionally zoned ash-flow sheet in southern Nevada. US Geol Surv Prof Pap 524-F:1-47

Macdonald GA, Katsura T (1965) Eruption of Lassen Peak, Cascade Range, California, in 1915: example of mixed magmas. Geol Soc Am Bull 76:475-482

Marsh BD (1981) On the crystallinity, probability of occurrence, and rheology of lava and magma. Contrib Mineral Petrol $78: 85-98$

Marsh BD (1988) Crystal capture, sorting, and retention in convecting magma. Geol Soc Am Bull 100:1720-1737

McBirney AR (1980) Mixing and unmixing of magmas. J Volcanol Geotherm Res 7:357-371

Oldenburg CM, Spera FJ, Yuen DA, Sewell G (1989) Dynamic mixing in magma bodies: theory, simulations, and implications. J Geophys Res 94:9215-9236

Ross CS, Smith RL (1961) Ash-flow tuffs: their origin, geologic relations and identification. US Geol Surv Prof Pap 366:1-81

Schmincke HU (1967) Cone sheet swarm, resurgence of Tejeda caldera, and the early geologic history of Gran Canaria. Bull Volcanol 31:153-162

Schmincke HU (1968) Faulting versus erosion and the reconstruction of the Mid-Miocene shield volcano of Gran Canaria. Geol Mittlg 8:23-50

Schmincke HU (1969a) Petrologie der phonolithischen bis rhyolithischen Vulkanite auf Gran Canaria, Kanarische Inseln. Habilitation thesis, Ruprecht-Karl Universität, Heidelberg, FRG, pp 151

Schmincke HU (1969 b) Ignimbrite sequence on Gran Canaria. Bull Volcanol 33:1199-1219

Schmincke HU (1982) Volcanic and chemical evolution of the Canary Islands. In: von Rad U, Hinz K, Sarnthein M, Seibold $E$ (eds) Geology of the northwest African continental margin. Springer, Berlin Heidelberg New York, pp 273-306

Schmincke HU (1990) Geological field guide Gran Canaria. With contributions from Freundt A, Ferriz H, Kobberger G and Leat P. Excursion 7BI International Volcanological Congress, Mainz, FRG, Pluto Press, Witten, pp 210

Schmincke HU, Swanson DA (1966) Eine alte Caldera auf Gran Canaria. N Jb Geol Paläont Mh 5:260-269

Schuraytz BC, Vogel TA, Younker LW (1989) Evidence for dynamic withdrawal from a layered magma body: the Topopah Spring Tuff, southwestern Nevada. J Geophys Res 94:5925-5942
Shaw HR (1972) Viscosities of magmatic silicate liquids: an empirical method of prediction. Am J Sci 272:870-893

Sigurdsson H, Sparks RSJ (1981) Petrology of rhyolitic and mixed magma ejecta from the 1875 eruption of Askja, Iceland. J Petrol $22: 41-84$

Smith RL (1979) Ash-flow magmatism. In: Chapin CE, Elston WE (eds) Ash-flow tuffs. Geol Soc Am Spec Pap 180:5-27

Smith RL, Bailey RA (1966) The Bandelier Tuff: a study of ashflow eruption cycles from zoned magma chambers. Bull Volcanol 29:83-104

Sparks RSJ, Marshall LA (1986) Thermal and mechanical constraints on mixing between mafic and silicic magmas. In: Kushiro I (ed) M Sakuyama, H Fukuyama memorial volume. J Volcanol Geotherm Res 29:99-124

Thompson RA, Dungan MA (1985) The petrology and geochemistry of the Handkerchief Mesa mixed magma complex, San Juan Mountains, Colorado. J Volcanol Geotherm Res 26:251274

Turner JS (1980) A fluid-dynamic model of differentiation and layering in magma chambers. Nature 285:213-215

Vogel TA, Wilbrand JT (1978) Coexisting acidic and basic melts: geochemistry of a composite dike. J Geol 86:353-371

Whitney JA (1988) The origin of granite: the role and source of water in the evolution of granitic magmas. Geol Soc Am Bull 100:1886-1897

Wiebe RA (1987) Evidence for stratification of basic, silicic, and hybrid magmas in the Newark Island layered intrusion, Nain, Labrador. Geology 15:349-352

Wilson L, Head III JW (1981) Ascent and eruption of basaltic magma on the Earth and Moon. J Geophys Res 86:2971-3001

Wörner G, Schmincke HU (1984) Mineralogy and geochemical evolution of the Laacher See magma chamber. J Petrol 25:805835

Wolff JA, Wörner G, Blake S (1990) Gradients in physical parameters in zoned felsic magma bodies: implications for evolution and eruptive withdrawal. J Volcanol Geotherm Res 43:37-55

Wright TL (1971) Chemistry of Kilauea and Mauna Loa lava in space and time. US Geol Survey Prof Pap 735:1-40

Wright TL, Fiske RS (1971) Origin of differentiated hybrid lavas of Kilauea volcano, Hawaii. J Petrol 12:1-65

Editorial responsibility: J Hoefs 